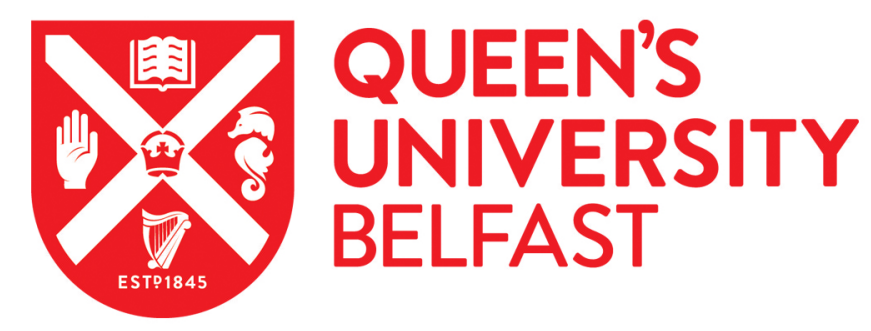

\title{
Removal of microorganisms and their chemical metabolites from water using semiconductor photocatalysis
}

Robertson, P. K. J., Robertson, J. M. C., \& Bahnemann, D. W. (2012). Removal of microorganisms and their chemical metabolites from water using semiconductor photocatalysis. Journal of Hazardous Materials, 211-212, 161-171. https://doi.org/10.1016/j.jhazmat.2011.11.058

Published in:

Journal of Hazardous Materials

Document Version:

Peer reviewed version

Queen's University Belfast - Research Portal:

Link to publication record in Queen's University Belfast Research Portal

Publisher rights

(C) 2011 Elsevier B.V.

This is an open access article published under a Creative Commons Attribution-NonCommercial-NoDerivs License

(https://creativecommons.org/licenses/by-nc-nd/4.0/), which permits distribution and reproduction for non-commercial purposes, provided the author and source are cited.

\section{General rights}

Copyright for the publications made accessible via the Queen's University Belfast Research Portal is retained by the author(s) and / or other copyright owners and it is a condition of accessing these publications that users recognise and abide by the legal requirements associated with these rights.

Take down policy

The Research Portal is Queen's institutional repository that provides access to Queen's research output. Every effort has been made to ensure that content in the Research Portal does not infringe any person's rights, or applicable UK laws. If you discover content in the Research Portal that you believe breaches copyright or violates any law, please contact openaccess@qub.ac.uk. 
Removal of microorganisms and their chemical metabolites from water using semiconductor photocatalysis

Peter K.J. Robertson ${ }^{a^{*}}$, J eanette M. C. Robertson ${ }^{a}$ and Detlef W. Bahnemann ${ }^{b}$ a IDeaS, Innovation, Design and Sustainability Research Institute, Robert Gordon University, Schoolhill, Aberdeen, AB10 1FR, UK.

bInstitut fuer Technische Chemie, Gottfried Wilhelm Leibniz Universitaet

Hannover, Callinstrasse 3, D-30167 Hannover, Germany.

*Corresponding Author phone: +44 1224 263750; fax: +44 1224 262759; email: peter.robertson@rgu.ac.uk 


\begin{abstract}
.
Semiconductor photocatalysis has been applied to the remediation of an extensive range of chemical pollutants in water over the past 30 years. The application of this versatile technology for removal of micro-organisms and cyanotoxins has recently become an area that has also been the subject of extensive research particularly over the past decade. This paper considers recent research in the application of semiconductor photocatalysis for the treatment of water contaminated with pathogenic micro-organisms and cyanotoxins. The basic processes involved in photocatalysis are described and examples of recent research into the use of photocatalysis for the removal of a range of microorganisms are detailed. The paper concludes with a review of the key research on the application of this process for the removal of chemical metabolites generated from cyanobacteria.
\end{abstract}

Keywords: Photocatalysis, $\mathrm{TiO}_{2}$, micro-organism, pathogen, disinfection, cyanobacteria, cyanotoxin. 


\section{Introduction}

Since the first reported studies on the ability of titanium dioxide photocatalysis to destroy microbial pathogens in water [1-3], numerous studies have been undertaken to further the knowledge and understanding of this process [4-12]. Early insights into the bactericidal mechanism of action of $\mathrm{TiO}_{2}$ photocatalysis were provided by Matsunaga et al [1] who demonstrated the direct oxidation of intracellular Coenzyme A in the bacteria Lactobacillus acidophilus and E. coli and in the yeast Saccharomyces cerevisia. This resulted in the inhibition of respiratory activity and eventual cell death. Later work by Saito et al [13] showed that cell death was accompanied by a rapid leakage of potassium ions along with the slow release of bacterial protein and RNA from Streptococcus sobrinus AHT. Results from transmission electron micrographs of treated S. sobrinus AHT showed that cell death was due to a significant disorder of cell membranes and cell wall decomposition. Further evidence for cell membrane involvement in the photocatalytic killing process was then demonstrated by several other groups [14-19].

This review will focus on recent developments in the area of photocatalytic destruction of microorganisms in water and on the challenges recent findings have presented for the real application of this technology to water treatment. In addition the use of semiconductor photocatalysis for the destruction of toxins released from cyanobacteria will also be considered. The World Health 
Organisation (WHO) has stated that microbial hazards are the primary concern for drinking water quality in both developed and underdeveloped countries. The greatest risk is associated with the consumption of water contaminated with human or animal faeces as these are a source of pathogenic bacteria, viruses, fungi, protozoa and helminths. Therefore the use of any technology which can improve the quality of drinking water will provide significant worldwide health benefits [20].

\section{Basic Processes in Semiconductor Photocatalysis}

The basic principle of semiconductor photocatalysis relies on the formation of an electron-hole pair upon the absorption of a photon with energy equal or bigger than the semiconductor's band-gap. These two highly reactive entities are consequently involved in all subsequent coupled reactions oxidizing and reducing the suitable species in the system concomitantly.

The photogeneration of an exciton is a well established process both in direct and in indirect semiconductors [21]. Photogenerated electrons need to react with a proper acceptor, in environmental photocatalysis this is normally assumed to be $\mathrm{O}_{2}$ forming initially a superoxide radical and finally ending up as $\mathrm{H}_{2} \mathrm{O}$, while the photogenerated holes, depending on their oxidizing power, are transferred to a mostly organic molecule inducing its oxidation. If this oxidation results in its complete degradation with the final products being $\mathrm{CO}_{2}, \mathrm{H}_{2} \mathrm{O}$ and eventually ionized halides, the organic compound is said to be mineralized. Inorganic pollutants can as well be converted into less toxic or 
less dangerous compounds $[22,23]$ by oxidation (reaction with holes) or reduction (reaction with electrons), while biological entities, e.g., macromolecules, bacteria, and viruses, can be killed or be removed entirely for disinfection.

The photocatalyst is therefore involved in the production of an oxidative and a reductive entity. In its first stage these are a photogenerated hole created in the valence band, $h_{V B}^{+}$and a photogenerated electron formed in the conduction band, $e_{C B}^{-}$:

Photocatalyst $\stackrel{h v}{\longrightarrow} e_{C B}^{-}+h_{V B}^{+}$

Eq. 1

Independently from the way the $h_{V B}^{+}$reach the surface, two different mechanisms may take place: (1) they are either transferred to the adsorbed pollutant causing its immediate oxidation (eq. 2), or (2) they are first transferred to adsorbed water molecules generating hydroxyl radicals, $\cdot \mathrm{OH}$, which upon reaction with the pollutant will produce the respective oxidation products (eq. 3 ).

$h_{V B}^{+}+$Pollutant $_{s} \rightarrow^{\bullet}$ Pollutant $_{s}^{+}$

Eq. 2

$\mathrm{h}_{\mathrm{VB}}^{+}+\mathrm{OH}_{\mathrm{s}} \rightarrow^{\bullet} \mathrm{OH}_{s}$

Eq. 3 
In eq. 3 , the suffix "s" in $\cdot \mathrm{OH}_{\mathrm{s}}$ indicates the formation of surface groups and can thus be interpreted as surface trapped holes.

Mechanism 1 is normally regarded as direct oxidation or direct photocatalysis, while mechanism 2 is called indirect oxidation or indirect photocatalysis. Mechanism 1 is associated with systems where the pollutant adsorbs strongly at the photocatalyst surface establishing a good electronic contact, while mechanism 2 will be dominant in systems with a weak pollutant adsorption. The pollutant's photo-oxidation via mechanism 2 will therefore be mediated by the action of $\mathrm{OH}_{\mathrm{s}}$, and depending on how long the - $\mathrm{OH}_{\mathrm{s}}$ need to migrate to meet the pollutant or how fast the latter can reach it, the photocatalytic oxidation rate will vary considerably. In principle, mechanism 2 can be as fast as mechanism 1 , or it will be slower, but it is highly unlikely to be faster.

The photogenerated hydroxyl radicals can react while being adsorbed at the photocatalyst's surface, $\cdot \mathrm{OH}_{\mathrm{s}}$ (eq. 4), or after having been desorbed, i.e., acting as free hydroxyl radicals in solution, $\cdot \mathrm{OH}_{\text {free }}$ (eq.5).

$\cdot \mathrm{OH}_{s}+$ Pollutant $\rightarrow$ Oxidation products

Eq. 4

$\cdot{ }^{\circ} \mathrm{OH}_{s} \stackrel{\text { desorption }}{\longrightarrow}{ }^{\circ} \mathrm{OH}$ free + Pollutant $\rightarrow$ Oxidation products $\quad$ Eq. 5

Systems in which the pollutant molecule is weakly adsorbed at the photocatalyst's surface are likely to be dominated by photocatalytic reactions 
such as shown in eq. 4 or 5 . Oxidation products will therefore be formed in the bulk liquid or gas phase, respectively, with a low probability of adsorption and eventual blocking or poisoning of the photocatalyst surface. This will be considerably different in systems where pollutants are strongly adsorbing. Photo-oxidation between two adsorbed species, i.e., $\cdot \mathrm{OH}_{\mathrm{s}}$ and Pollutants surely demands a rather high surface mobility of these species, and cannot be disregarded since surface diffusion is considerably faster than diffusion from the bulk. Moreover, on nanoparticles the distances between $\cdot \mathrm{OH}_{\mathrm{s}}$ and Pollutant $_{s}$ might be small enough to allow electron transfer through tunnelling mechanisms.

Bahnemann et al, by means of time-resolved laser flash photolysis [24], identified two types of traps for holes: deep traps which are long-lived and unreactive and shallow traps in thermally activated equilibrium with $h_{V B}^{+}$ exhibiting a high oxidation potential. According to Monllor-Satoca et al [25], the unreactive deep traps might correspond to the intrinsic $\cdot \mathrm{OH}_{\mathrm{s}}$. In this case, the reactive shallow traps can be assigned to $h_{V B}^{+}$, and in a similar manner as the direct hole transfer to adsorbed pollutants occurs, extrinsic $\cdot \mathrm{OH}_{\mathrm{s}}$ will be generated, since in both cases the adsorption occurs at unsaturated $\mathrm{Ti}$ surface atoms (eq. 2 and 3). Compounds that adsorb strongly on the surface of metal oxide particles usually form covalent bonds employing one, two, or three $\mathrm{O}$ atoms (to form mono-, bi- or three-dentate complexes) as it is the case for alcohols [26] and organic acids [27-29]. The reaction can be schematically described: 
$\mathrm{Ti}_{s}+\mathrm{HO}-\mathrm{R} \stackrel{\text { adsorption }}{\longrightarrow} \mathrm{Ti}_{s}-\mathrm{OR}^{-}+H_{a q}^{+} \quad \mathrm{R}=$ organic moeity $\quad$ Eq. 6

It should be noted, however, that the formation of $\cdot \mathrm{OH}$ can as well follow a reductive pathway [30]:

$e_{\mathrm{CB}}^{-}+\mathrm{O}_{2} \rightarrow \mathrm{O}_{2}^{\cdot-} \stackrel{e^{-} 2 \mathrm{H}^{+}}{\longrightarrow} \mathrm{H}_{2} \mathrm{O}_{2} \stackrel{e^{-}}{\longrightarrow}{ }^{\bullet} \mathrm{OH}+{ }^{-} \mathrm{OH}$

Eq. 7

with the $e_{C B}^{-}$converting the oxidant species, i.e., $\mathrm{O}_{2}$, into $\mathrm{H}_{2} \mathrm{O}_{2}$ which is then further reduced yielding hydroxyl radicals. Although $\mathrm{H}_{2} \mathrm{O}_{2}$, should be formed as a rather stable product by the further reduction of $\mathrm{O}_{2}^{--}$, it is only found in traces when working with $\mathrm{TiO}_{2}$ powders [31], since by its subsequent reduction, very likely, $\cdot \mathrm{OH}$ is formed.

In some systems mechanism 1 (eq. 2) appears to be uniquely responsible for the photocatalytic reaction, e.g., in the case of the photocatalytic degradation of formic acid [25], acetic acid [25], and oxalic acid [32]. Mechanism 2 (eq. 3) dominates other photocatalytic systems, e.g., the photooxidation of methanol [25], chloroform [25], methylviologen [25], 2propanol [25], and phenol [25]. In some cases, both mechanisms can take place at the same time, for instance, depending on the illuminating photon flux, some systems may experience a transition from an indirect to a direct 
mechanism, where a low photo flux favours an indirect mechanism and a high photon flux a direct one [25].

In general, regardless of the reaction in which the photogenerated charge carriers are involved, they are definitively leading to a complex set of subsequent reactions, resulting altogether in the so-called semiconductor photocatalytic activity. The photocatalytic reaction in a whole can proceed via several different mechanisms which may take place all at once, one after another, or some of them only in a few particular cases.

\section{Photocatalytic Destruction of Micro-organisms}

The usefulness of photocatalysis for the disinfection of water has been shown by the destructive effects it has on a wide range of microorganisms i.e. bacteria [33-43] viruses [44-47], fungi [48-52] and protozoa [53-55].

Many studies have examined the role of experimental variables on the response of microorganisms to photocatalytic treatment. These have included the effects of aeration, $\mathrm{pH}$, chemical nature of bacterial suspension medium, photocatalyst type and concentration, light intensity and treatment time [39, 49, 55-62]. While these experimental parameters have been shown to affect microbial response to photo inactivation, consideration must also be given to the nature of the organism targeted. Some studies have shown that the response time of different microorganisms to photocatalytic inactivation is related to cell wall complexity. Microorganisms with a more complex cell wall have been shown to be more resistant to photocatalytic treatment. The 
response of microorganisms to photocatalytic treatment has been reported to follow the order of protozoa being the most resistant followed by bacterial spores, mycobacteria, viruses, fungi and bacteria [61].

Furthermore the difference in cell wall complexity between gram positive and gram negative bacteria has also been shown to affect treatment time. Gram positive bacteria like enterococci require a longer treatment time than gram negative bacteria such as coliforms [59]. This is because gram positive bacteria have a very thick cell wall consisting of many layers of peptidoglycan and teichoic acids. On the other hand the cell wall of gram negative bacteria is very thin consisting of only a few layers of peptidoglycan surrounded by a second lipid membrane containing lipopolysaccharides and lipoproteins.

In addition some disease causing bacterial species can produce highly resistant structures known as endospores (spores), the role of which is to enable the bacteria to withstand unfavourable conditions. Spores are more resistant to physical destruction e.g. heat, radiation and desiccation, than vegetative cells. Consequently they require longer treatment time to be destroyed by photocatalytic means. Indeed many successful reports on the destruction of bacterial spores have come from studies which have employed additional ways of improving photocatalytic efficiency [35, 63, 64]. Dunlop et al [63] showed that electrochemically assisted photocatalytic disinfection significantly increased the rate of disinfection of Clostridium perfringens spores compared to open circuit conditions. Polo-López et al [65] highlighted 
that, as with vegetative cells, differences in external spore wall structure have an impact on the response of microbial spores to photocatalytic treatment. They demonstrated a direct correlation between the sensitivity of Fusarium spp. spores to photocatalytic treatment and external spore wall complexity. The most complex spores, chlamydospores were shown to be the most resistant to treatment, followed by macroconidia and finally microconidia.

The impact of bacterial factors such as expression of cell surface structures and enzymes should not be overlooked when considering variables that affect the microbial response to photocatalytic treatment. Leung et al [43] examined the photocatalytic disinfection of the marine bacteria Alteromonas alvinellae and Photobacterium phosphoreum. P. phosphoreum was shown to be less susceptible than $A$. alvinellae to photocatalytic treatment which authors stated was related to differences in their fatty acid profiles and levels of superoxide dismutase (SOD) and catalase (CAT). SOD and CAT are bacterial intracellular enzymes which have a role in protecting bacteria from oxidative stress induced by their environment. The authors stated that higher SOD and CAT levels implied bacteria could defend themselves against .OH attack from photocatalysis to a greater extent.

Despite the number of studies undertaken to elucidate the mechanism of photocatalytic disinfection, the exact mode of action is yet to be shown. The antibacterial properties of $\mathrm{TiO}_{2}$ photocatalysis are due to the generation of reactive oxygen species of which hydroxyl radicals are considered to be the 
most important. The accepted sequence of events which take place when microorganisms undergo $\mathrm{TiO}_{2}$ photocatalytic attack are thought to be cell wall damage followed by cytoplasmic membrane damage leading to a direct intracellular attack. Recently more sophisticated methods have been used to give further insight into this mechanism [67-70]. Goulhen-Chollet et al [70] used a biochemical approach to assess this mode of action of $\mathrm{TiO}_{2}$ photocatalysis. Using 1D and 2D sodium dodecyl sulfate-polyacrylamide gel electrophoresis they showed that model proteins and bacterial proteins were quickly degraded during photocatalytic treatment resulting in a loss of cell activity and eventual cell death. They did not find a particular protein target and suggested that this indicated that the development of bacterial resistance to this form of treatment was almost impossible. Wu et al [67] used scanning electron microscopy to investigate of cell morphology of E. coli treated with a PdO/TiON photocatalyst. While the surface of control bacteria remained continuous and free of any damage those irradiated with visible light in the presence of the catalyst showed damaged membranes containing pits and holes in their cell walls. More recently, Pigeot-Rémy et al [68] examined the morphological damage irradiated $\mathrm{TiO}_{2}$ caused to E. coli K-12, using transmission electron microscopy (figure 1). Bacteria were no longer cultivable after $1.5 \mathrm{hr}$ and membrane structure was disorganised at this point. They also observed the concomitment release of chemical by-products such as oxamic and oxalic acids as well as ammonium cations, sulfate and nitrate anions. They suggested that these results correlated with nucleic acid 
damage and showed using electrophoresis that bacterial DNA and RNA had completely disappeared after $7 \mathrm{hr}$ of photocatalytic treatment.

Figure 1.

When considering the application of this technology for the disinfection of real water it should be taken into consideration that the response of bacteria to photocatalytic treatment in laboratory water samples differs greatly from those in real water samples such as wastewater or river water $[37,56,58$, $60,71,72]$. The presence of suspended solids dissolved inorganic ions and organic compounds (mainly humic substances) and dissolved oxygen are thought to affect the efficacy of photocatalysis [72]. The issue of bacterial regrowth following photocatalytic treatment has been addressed by several authors $[37,57,73-75]$. Not surprisingly there is some variation in the conclusions reached particularly when comparing laboratory water samples and natural water samples. Rincon and Pulgarin reported no bacterial regrowth following treatment of E. coli k12 contaminated water in a compound parabolic collector (CPC) reactor irradiated under direct sunlight. They stated that monitoring the bacterial population following treatment was very important since by-products photogenerated from organic matter naturally present in water or those present as a result of bacterial lysis could offer favourable conditions for bacterial regrowth [75]. Moreover this paper reported a residual disinfection effect in which the decrease in bacterial numbers continued in the dark after the phototreatment ceased (figure 2). This was suggested to be due to radicals and other oxidative species, 
produced during phototreatment, inducing damage that continues to affect the bacteria in the dark.

Figure 2.

Alrousan et al [72] used immobilised nanoparticle $\mathrm{TiO}_{2}$ films to show that deactivation rates of E. coli were significantly lower in surface water samples compared to distilled water. They found that the organic and inorganic content of surface water lead to a reduction in the rate of photocatalytic disinfection (compared to results for distilled water) with the greatest decrease caused by the presence of humic acid. Lydakis-Simantiris et al [59] examined the disinfection of natural spring water and secondary treated municipal wastewater by $\mathrm{TiO}_{2}$ photocatalysis. As with other groups, this work showed that the gram positive bacteria (Enterococcus spp.) was much more resistant to photocatalytic treatment that the gram negative bacteria (total coliforms) however after 60 min irradiation time with 1g/L Degussa P25 $\mathrm{TiO}_{2}$, small numbers of both faecal pathogens survived. They suggest this persistence may be due to the presence of dead bacteria and their excreted intracellular components competing with live bacteria for photogenerated hydroxyl radicals and/or forming a screen to reduce light penetration.

In addition, bacteria present in natural water samples are likely to be at different stages of growth. Therefore the impact of bacteria growth phase on response to photocatalytic treatment must be taken into consideration during 
experimental design to ensure the efficacy of bacterial inactivation by the photocatalytic process. Leung et al [43] investigated the susceptibility of mid-log, late- log and stationary phase cells of the marine bacteria Alteromonas alvinellae and Photobacterium phosphoreum to photocatalytic treatment. They showed that no significant difference was observed for inactivation of $\mathrm{P}$. phosphoreum during the three growth stages. A. alvinellae on the other hand showed higher resistance to photocatalytic treatment in late- log phase, which the authors suggested was related to lower levels of SOD and CAT expression.

The use of solar irradiation to disinfect natural water sources enhances the attractiveness of this technology particularly for use in remote areas [49, 55, 60-62, 65, 75-78]. While solar irradiation has many advantages e.g. readily available, cost effective, it does suffer from the drawback of not being able to control irradiation output. Therefore on cloudy days, photocatalytic efficiency may be reduced. Sichel et al [49], however, looked at the dependence of solar water disinfection on solar irradiation conditions under natural sunlight. Using E. coli k-12 and the fungal pathogens Fusarium solani and Fusarium anthophilum they showed that once the minimum solar dose had been received, photocatalytic disinfection efficiency wasn't enhanced by any further increase in light intensity (figure 3).

Figure 3. 
The use of $\mathrm{TiO}_{2}$ in suspension requires that it be removed from the water after treatment in order that it can be reused. One way of addressing this problem is by the use of immobilised or fixed catalyst systems. Moreover, studies have shown that immobilized systems are stable and are therefore readily applicable for continuous water treatment systems [36, 78-82]. One drawback, however, with using immobilised catalysts is the longer time required to inactivate microorganisms compared with that for catalysts in suspension [78]. This is thought to be due to the reduced interaction between the catalyst surface and the target microorganism [78]. van Grieken et al [79] compared the photocatalytic disinfection capability of a $\mathrm{TiO}_{2}$ slurry and immobilised in an annular reactor. Using E. coli as a model organism they showed that while the immobilised system showed a lower disinfection activity than the slurry, the former was less inhibited by the presence of organic matter which leads to comparable irradiation times required for bacterial inactivation in wastewater effluent. Gomes et al [78] investigated the inactivation of E. coli under natural sunlight in suspension or supported on Ahlstrom paper fixed around concentric tubes inside a photoreactor and showed that inactivation was more efficient with suspended $\mathrm{TiO}_{2}$. They suggested that the interaction between the bacteria and the supported $\mathrm{TiO}_{2}$ was the reaction constraint, reducing significantly the bacteria inactivation, as indicated by the values of the pseudo-adsorption constants. In addition the release of organic matter from the paper support was also responsible by the absorption of UV light, radical scavenging and inhibition of the catalyst as well as possibly acting as a nutrient supply for the bacteria Pablos et al [80] 
used epifluoresence microscopy to highlight mechanistic differences in bacteria-catalyst interaction between immobilised and fixed $\mathrm{TiO}_{2}$. They showed that while the irradiation time required to achieve total bacterial inactivation was comparable for both systems, the slurry system showed a higher inactivation rate at the beginning of the reaction that decreases progressively, whereas with the fixed-bed reactor the inactivation rate increased with increasing irradiation time. They suggested that this mechanistic difference made the immobilised system a more attractive option for scaling up the photocatalytic disinfection technology.

Since the activation of $\mathrm{TiO}_{2}$ is limited by a narrow wavelength spectrum, much research has been undertaken into ways of augmenting photocatalytic activity to enhance this activity. This has included the use of dopants, the application of an electric current and the addition of $\mathrm{H}_{2} \mathrm{O}_{2}$. Dopants are metal ions that can shift absorption of the photocatalyst to the visible region, the advantage of which is that it negates the use of UV light. Many studies have shown that doping has produced effective photocatalysts capable of destroying pathogenic microorganism under visible light [83-87]. RengifoRengifo- Herrera et al [83] showed that N, S co-doped Degussa P-25 powders were very effective in inactivating E. coli using visible light (figure 4). They suggested that the electron photo-promoted from the localized $\mathrm{N}$ and S states was the charge carrier responsible of the ROS formation. The main oxidative species were suggested to be the superoxide radical $\left(\mathrm{O}_{2}^{-}\right)$and singlet oxygen $\left({ }^{1} \mathrm{O}_{2}\right)$. 
Figure 4.

Other effective dopants include copper [84], palladium oxide [67], platinium [86] and silver [36,46, 87]. Liga et al [46] showed that silver doping of $\mathrm{TiO}_{2}$ nanoparticles significantly enhanced bacteriophage MS2 inactivation and that the inactivation rate increased with silver content. While van Grieken et al [36] showed that although the incorporation of silver into Degussa $\mathrm{TiO}_{2}$ powder increased the disinfection efficiency of E. coli, this increase in activity was not due to an enhanced photocatalytic mechanism but rather it was the result of the bactericidal role of silver. Recently Kowal et al [87] showed that doping titania with silver provided an anti-MRSA and anti-MSSA effect without an exposure to UV radiation.

Many studies have reported that the addition of $\mathrm{H}_{2} \mathrm{O}_{2}[56,74,75]$ greatly enhances photocatalytic efficiency. Rincon and Pulgarin [74, 75] showed that the addition of $\mathrm{Fe}^{3+}$ and $\mathrm{Fe}^{3+} / \mathrm{H}_{2} \mathrm{O}_{2}$ resulted in improved rates of disinfection of water contaminated with E. coli K12 in a CPC reactor using solar irradiation and no bacterial regrowth was detected during the subsequent 24 $\mathrm{hr}$ period in the dark. Several studies have made use of the process of photoelectrocatalysis i.e. a process that combines electrochemistry with photocatalysis to effectively suppress the recombination of photoelectrons and holes and enhance photocatalytic disinfection efficiency [47, 88 - 91]. Baram et al [88] showed that electrochemically assisted solar photocatalysis efficiently destroyed E. coli after only 10 minutes treatment time. Li et al [91] showed that photoelectrocatalysis (performed under a $+0.30 \mathrm{~V}$ (vs. $\mathrm{Ag} / \mathrm{AgCl}$ ) applied potential bias) was more effective in destroying E.coli than 
photocatalysis alone. Cho et al [47] recently examined the inactivation of MS-2 bacteriophase in a $\mathrm{TiO}_{2}$ photoelectrocatalytic system. They showed that the application of anodic potential to $\mathrm{TiO}_{2}$ greatly enhanced inactivation of MS-2 and Cryptosporidium parvum oocyst as well as a range of gram positive and gram negative bacteria. They found that applying a positive potential also reactive oxygen species production.

The World Health Organization has stated that securing the microbial safety of drinking-water supplies is increased if multiple barriers are in place. These include the protection of water resources, proper selection and operation of a series of treatment steps and management of distribution systems to maintain and protect treated water quality. While the application of titanium dioxide photocatalysis as an additional barrier in this process is a real possibility there is still much work to be done in this area to ensure the reliability and efficacy of this process.

Table 1 gives an overview of the main microorganisms that have been studied in the past five years

\section{Photocatalytic Destruction of Cyanotoxins}

In addition to the challenges of pathogenic micro-organisms contaminating water there has been a growing problem in terms of the occurrence of cyanobacterial blooms, resulting from factors such as increased nutrient levels in water from intensive farming $[92,93]$. There are a number of genera of cyanobacteria including Microcystis, Oscillatoria, Anabaena and 
Aphanizomenon which generated neurotoxins including anatoxin-a, anatoxina(s) and saxitoxins or hepatotoxins such as microcystins or nodularin. The heptapeptide Microcystins are heptapeptides and over 60 congeners have been detected (figure 5). Microcystins primarily known as potent inhibitors of serine/threonine protein phosphatase 1 (PP1), PP2A, PP3 and PP4 [94-96]. At higher doses microcystins cause acute hepatic failure and were associated with the death of patients undergoing dialysis in Brazil in 1996 [97]. In addition to microcystins cylindrospermopsin was also detected in the contaminated water. As a result of the concern of the potential tumour promoting activity of microcystins and the World Health Organisation have published of a Guideline Value for microcystins of $1 \mu \mathrm{g} \mathrm{dm}^{-3}$ in potable water. Microcystins are however very stable molecules and it has been suggested that conventional water treatment systems may be undependable for the elimination of these toxins from potable water [98-100].

Figure 5.

The application of semiconductor photocatalysis for the removal of cyanotoxins has been comprehensively investigated since the first report in 1997 [101]. Using a P25 material a rapid destruction of microcystin-LR was achieved [101]. The photocatalytic decomposition process was found to depend on a number of parameters including toxin concentration, $\mathrm{pH}$ and light intensity [102].

In a subsequent study, Robertson et al, reported that when the 
photocatalytic decomposition reaction was performed in heavy water, a kinetic solvent isotope effect of approximately 3 was obtained (Figure 6) [103]. In addition a number of hydroxylated products were detected using mass spectrometry. This resulted suggested that the primary mode of attack on the microcystin was via hydroxyl radicals generated on the titanium dioxide surface. In this paper it as also reported that no photocatalytic degradation proceeded under a nitrogen atmosphere.

Figure 6

The mechanism of the photocatalytic destruction of microcystin was studied in more detail by Lawton et al who studied the decomposition products using liquid chromatography [104]. In this paper a total of seven UV detectable products were generated as part of the photo catalytic reaction. Six of these products, however, did not undergo further decomposition on continued photocatalysis. In total only $10 \%$ of the microcystin was completely mineralised. The toxicity of the by-products was consequently assessed using both brine shrimp and protein phosphatase bioassays [105]. No residual toxicity was detected using either bioassay on extended photocatalysis (figure 7).

Figure 7. 
Antoniou et al studied the photocatalytic oxidation of microcystin-LR on transparent thin $\mathrm{TiO}_{2}$ films [106]. Specifically they investigated the effect of $\mathrm{pH}$, toxin concentration, $\mathrm{TiO}_{2}$ coated film surface area and film structural properties on the rate of toxin destruction. The best performance for toxin destruction was achieved using a $0.3 \mu \mathrm{M}$ coating under both acidic and neutral $\mathrm{pH}$ conditions. Protein phosphatise bioassay demonstrated that removal of microcystin-LR toxicity had been achieved. Although acidic pH favoured the photocatalytic decomposition of the microcystins, it was reported that acidic $\mathrm{pH}$ limited the available sites of the toxin for degradation to the diene bonds of Adda and the double bond of MeAsp. Under neutral conditions, however, the methoxy and the aromatic groups of the Adda part of the microcystin structure were involved. Structures for the interaction of the microcystins and the $\mathrm{TiO}_{2}$ photocatalyst, under acidic conditions, were proposed by Antoniou et al [106].

A more detailed assessment of the mechanism of the photocatalytic decomposition of microcystin-LR was performed by Liu et al using LCMS [107]. In this study it was reported that the destruction of the cyanotoxin was initiated by three major pathways. These were a UV transformation, hydroxyl radical attack and a direct oxidation of the substrate. Song et al. [108] demonstrated that the photoisomerisation of microcystin-LR could not be achieved using UVA light and UVC was required to induce this transformation. In a detailed study of the mechanism of the photocatalytic decomposition of microcystin, Antoniou et al [109] reported that the 
mechanism of the addition of hydroxyl radicals to the diene bonds could induce this isomerisation.

Antoniou et al $[109,110]$ studied the reaction intermediates generated in the photocatalytic destruction of microcystin- $\mathrm{LR}$ using $\mathrm{TiO}_{2}$ photocatalysts immobilised to glass [109] and stainless steel [110]. At pH 5.7 a total of eleven new intermediates were observed many of which were not reported in the study by Liu [107]. It was reported that acidic conditions were favoured in the photocatalytic destruction process. Furthermore with the lower surface area of the films compared to powder suspension the degradation rate was believed to be slower resulting in more intermediates being generated.

The decomposition of a series of different microcystin variants, - LR, -YR and -YA was subsequently described by Shepard et al [111]. Each of the variants was decomposed within 20 minutes and each process had a half life of less than 5 minutes.

Feitz et al. [112] studied the effect of pH on the photocatalytic degradation of microcystin-LR. It was found that this was greatest at a pH level of 3.5, a level at which dark adsorption was also at a maximum. A detailed study of the influence of $\mathrm{pH}$ on the photocatalytic destruction of a series of microcystins including microcystin-LR, -RR, - LW and - LF was described by Lawton et al [113]. It was reported that the initial rate of the cyanotoxin destruction was strongly influenced by the $\mathrm{pH}$ level and this correlated well with the corresponding level of dark adsorption. This influence was believed 
to be due to a combination of effects including the hydrophobicity and overall charge of the microcystin variants. In addition the rates were believed to be influenced by the surface charge of the photocatalyst material as this varied around the point of zero charge for Degussa $\mathrm{P} 25 \mathrm{TiO}_{2}$ at $\mathrm{pH} 6.25$ which also affected the dark adsorption of the cyanotoxins.

The addition of additives such as hydrogen peroxide or ferrate has been demonstrated to have a positive enhancement on the photocatalytic decomposition of microcystins. Cornish et al [114] reported a significant improvement on the photocatalytic destruction of microcystin-LR when small quantities of hydrogen peroxide were added to the reaction matrix (figure 8). The overall effect was however strongly dependent on the quantity of peroxide added, with an ideal peroxide loading of between 0.005 and $0.1 \%$ being reported. At peroxide concentrations above this level the rate of microcystin decomposition started to decline and it was believed this was due to a competitive adsorption of the peroxide with the toxin [114]. It was also reported that when peroxide was added fewer decomposition products were detected by liquid chromatography. Furthermore there was also a more rapid reduction in the toxicity of the treated water when peroxide was added as indicated by both brine shrimp and protein phosphatase bioassays [105].

Figure 8.

The photocatalytic destruction of microcystin-LR was also significantly enhanced by the addition of ferrate [115]. Up to $63 \%$ of a $2 \mathrm{mg} \mathrm{l}^{-1}$ solution of microcystin was destroyed after 30 minutes photocatalysis, which was 
reported to be 4.4 times greater than the level achieved in the absence of Fe ions. This process was also reported to be strongly dependent on $\mathrm{pH}$ level with this being maximised at $\mathrm{pH} 6$.

Liu et al [116] reported the photocatalytic destruction of microcystin-LR on a number of commercially available $\mathrm{TiO}_{2}$ powder (P25, PC50, PC500 and UV100) (figure 9) and granular (KO1, KO3, TiCat-C, TiCat-S) materials. Using liquid chromatography-mass spectrometry analysis it was established that the primary decomposition pathway of the cyanotoxin was the same for all the photocatalyst materials examined. This observation suggested that the physical properties of the catalysts had little influence on the photocatalytic degradation pathway of microcystin-LR.

One of the main challenges in developing a photocatalytic process that can be applied to large scale water treatment has been the development of a visible light absorbing photocatalyst. A nitrogen-doped $\mathrm{TiO}_{2}$ visible light absorbing photocatalyst was used by Choi et al [117] in the destruction of microcystin-LR. Under irradiation of light at $420 \mathrm{~nm}$ a $100 \%$ destruction of a $5 \mathrm{mM}$ microcystin-LR solution was achieved. Under the same experimental conditions only $10 \%$ toxin destruction was observed using a Degussa P25 photocatalyst. Pelaez et al. [118] utilised N-F-codoped $\mathrm{TiO}_{2}$ nanoparticles for the photocatalytic destruction of microcystin-LR using visible light at $420 \mathrm{~nm}$. This process was found to be most favourable at $\mathrm{pH} 3$ where complete toxin destruction was achieved within 300 min. It was proposed that at this $\mathrm{pH}$ the 
adsorption of the catalyst was maximised through and electrostatic interaction between the microcystin and the photocatalyst. The application of $\mathrm{TiO}_{2}-\mathrm{Pt}$ (IV), $\mathrm{TiO}_{2}-\mathrm{C}, \quad \mathrm{TiO}_{2}-\mathrm{Rh}$ (III) materials, for the visible light photocatalytic degradation of microcystin-LR was reported by Graham et al. [119] The $\mathrm{TiO}_{2}-\mathrm{Rh}$ (III) proved to be the most effective material $100 \%$ of the toxin being decomposed with 60 minutes. The next most efficient materials were the platinum and carbon doped materials which destroyed $90 \%$ and $80 \%$ of the microcystin within 60 minutes respectively. Pelaez et al [120] investigated the effect of a range of water parameters in the degradation of microcystin-LR using the nitrogen and fluorine doped $\mathrm{TiO}_{2}$ photocatalyst. These parameters included $\mathrm{pH}$, alkalinity dissolved oxygen and naturally occurring organic materials (NOM) such as humic acid. As with previous reports the degradation was most efficient under acid conditions. Increasing concentrations of carbonate and NOM reduced the rate of destruction. Interestingly when natural water was spiked with microcystin and irradiated with artificial light at greater than $420 \mathrm{~nm}$ no degradation of the toxin was observed. When a similar system was irradiated with sunlight over $90 \%$ of the toxin was removed within five hours irradiation. This was believed to be due to NOM acting as a photosensitiser for the solar photocatalytic degradation of the toxin. This observation may be supported by the observation by Robertson et al [121] who previously reported that the phycocyanin pigment generated by cyanobacteria were involved in the photosensitised degradation of microcystin-LR. 
Less work has been reported on the removal of other cyanobacterial toxins from water. Nodularins are pentapeptide cyanotoxins produced by the cyanobacteria, Nodularia spumigena, they are tumour-promoters and their presence in drinking water is considered to play a role in the development of primary liver cancer in humans. It is therefore imperative that effective methods for their removal from drinking water sources are sought. $\mathrm{TiO}_{2}$ photocatalysis has also been applied to the destruction of the, nodularin from water [122]. As was the case with microcystin-LR the nodularin was rapidly decomposed with the corresponding elimination in toxicity. The photocatalytic process also eliminated the major by-products of the decomposition process. This was demonstrated using LC-MS where all were detectible products completely degraded within 100 minutes photocatalysis. Again in a similar manner to the photocatalytic destruction of microcystin-LR, the major pathway of the photocatalytic decomposition process appeared to involve isomerisation, substitution and cleavage of the Adda conjugated diene structure in either nodularin or its resulting derivatives.

Cylindrospermopsin is a cyanotoxin produced by Cylindrospermopsis raciborskii. This organism is regularly found in reservoirs in SouthEast Queensland, Australia where its presence has resulted in the closure of these reservoirs [123]. Senogles et al [123] reported on the photocatalytic destruction of this toxin using two commercially available types of $\mathrm{TiO}_{2}$; Degussa P25 and Hombikat UV-100. Using a cell free extract of 
Cylindrospermopsis raciborskii the authors used HPLC-tandem mass spectrometry to assess the effect of several variables on response of toxin to photocatalytic destruction. Variables examined were $\mathrm{pH}$, temperature, toxin concentration and dissolved organic carbon concentration. Overall Degussa $\mathrm{P}-25$ was found to be the more efficient catalyst and $\mathrm{pH}$ was the experimental variable shown to have the greatest influence on toxin degradation, regardless of catalyst type. The highest rate of toxin degradation was observed with $\mathrm{pH} 9$, this is in contrast to findings for microcystin - LR destruction which has been reported to take place more effectively at low pH [113]. As with destruction of bacteria, differences in the photocatalytic destruction rates of cyanobacterial toxins in natural water samples and laboratory water have been reported [123]. Unlike bacteria, however, the presence of dissolved organic carbon has been reported to enhance destruction of cylindrospermopsin [123]. Senogles et al [123] suggested that the enhanced destruction of cell free extracts of Cylindrospermopsis raciborskii in spiked natural water compared with those in laboratory water where due to the presence of organic and inorganic matter in the natural water.

As with any photocatalytic reactor system, the use of fixed $\mathrm{TiO}_{2}$ is preferable to $\mathrm{TiO}_{2}$ in suspension to avoid the problem of slurry removal following water treatment. Anabaena (as well as microcystis) were successfully destroyed using $\mathrm{TiO}_{2}$ coated Pyrex glass beads in the presence of UV light [124]. The 
authors stated that this method could successfully be employed for the practical application in a eutrophicated river using natural sunlight.

In addition to toxin production, cyanobacteria also produce non-toxic compounds which can affect water quality. Geosmin (GSM) and 2methylisoborneol (MIB) are bi-cyclic tertiary alcohols produced by cyanobacteria, which can taint water and fish and also give them an unpalatable earthy-musty flavour. It is therefore desirable that these compounds also be removed from drinking water supplies and in the aquaculture industry. Lawton et al [125] demonstrated the rapid destruction of MIB and GSM using $\mathrm{TiO}_{2}$ photocatalysis, as measured by GC-MS. Using concentrations of both compounds representative of those found in the environment, a greater than $99 \%$ reduction of both compounds was achieved within $60 \mathrm{~min}$. irradiation time [125]. Yoon et al [128] highlighted the effectiveness of $\mathrm{TiO}_{2}$-entrapped EFAL (extra-framework-aluminium)removed Y-zeolites $\left(\mathrm{TiO}_{2}\right.$-EFAL-removed Y-zeolites) for removing taint compounds, such as 2-methylisoborneol (2-MIB), in water. Results of kinetic studies showed that $\mathrm{TiO}_{2}$-EFAL-removed Y-zeolites were highly adsorptive and had higher photocatalytic quantum efficiency than that of Degussa P-25 $\mathrm{TiO}_{2}$.

Marine algal toxins are responsible for huge economic losses in the fishing industry. Moreover most have deleterious effects on human health which often occurs following consumption of shellfish which have fed on the algae. Several studies have however reported on the effectiveness of $\mathrm{TiO}_{2}$ 
photocatalysis in destroying these toxins. Djaoued et al [129] showed nanocrystalline titania thin films effectively degraded the marine neurotoxin, domoic acid. This toxin which is common in American coastal waters is particularly problematic in the shellfish and crustacean harvesting industry. During photocatalytic treatment the authors noted the presence, transformation and degradation of various isomers of domoic acid, as measured by HPLC.

One of the limiting factors of any photocatalytic reaction is the interaction of the catalyst with its target. Tominaga et al [130] produced a surface modified $\mathrm{TiO}_{2}$ to study the degradation of the paralytic shellfish toxin; saxitoxin. The hybrid photocatalysts were developed by introducing molecular recognition sites to the surface of $\mathrm{TiO}_{2}$ nanoparticles using a hydration-dehydration process or by silane coupling reaction and free radical polymerization (figure 1 from reference). Catalysts from both synthesis methods were shown to selectively degrade saxitoxins. The authors suggested it was the initial adsorption selectivity which affected toxin degradation rates. Brevetoxins are neurotoxins produced by the harmful marine algae Karenia brevis. Their presence in water is often indicated by the appearance of red tide which is the result of the release of photosynthetic coloured pigments from ruptured cells. Removal of brevetoxins from water sources using UV and solar photocatalysis has been examined by Khan et al [131]. Greatest toxin destruction was observed using UV light although sunlight was also effective. Furthermore as with most bacterial studies, 
photocatalytic destruction was faster in laboratory water than in synthetic seawater, this was considered to be due to the presence of humic substances and other ions present in seawater which reduce the efficiency of photocatalytic degradation [131].

Table 2 summarises the range of metabolites that have been successfully destroyed using semiconductor photocatalysis.

\section{Conclusions.}

Semiconductor photocatalysis has proven to be an effective method for the removal of micro-organisms and cyanotoxins from water. Over the past decades there have been a number of attempts to develop an understanding of the precise mechanism of the photocatalytic oxidation of bacterial species. While significant progress has been made there is still much research that needs to be undertaken before the process is fully understood. With respect to cyanotoxins such as microcystins, $\mathrm{TiO}_{2}$ photocatalysis has proven be particularly effective compared to traditional water treatment processes such as activated carbon or chlorination. The main challenges that are limiting the wide scale adoption of this process as a practical water treatment process is the lack of commercially available visible light absorbing photocatalyst materials and to date the process has only been scaled to a pilot level. The development of an effective, commercially available, visible light absorbing photocatalyst will be an important step in assisting the scale-up of the photocatalytic water treatment process. The strong attenuation of UV light by 
water, particularly natural waters contaminated by micro-organisms reduces the efficiency and hence increases the energy cost of photocatalytic water treatment. Visible light is less attenuated and also a greater portion of the sun's spectrum could be utilised enabling solar activated processes to be adopted. In order for this technology to be adopted as a practical water treatment process, ultimately it will be necessary to demonstrate the process is capable of treating thousands of $\mathrm{m}^{3}$ volumes per hour whether or not the system is activated by visible or UV light. 


\section{References}

[1]. T. Matsunaga, R. Tomoda, T. Nakajima, H. Wake , Photoelectrochemical sterilization of microbial cells by semiconductor powders, FEMS Microbiol. Lett. 29 (1985) 211-214.

[2]. J.C. Ireland, P. Klostermann, E.W. Rice and R.M. Clarke, Inactivation of Escherichia coli by Titanium Dioxide Photocatalytic Oxidation, Applied and Environmental Microbiology, 59 (1993) 1668-1670.

[3]. C. Wei, W. Y.Lin, Z. Zainal, N.E. Williams, K. Zhu, A. P. Kruzic, R. L. Smith, K. Rajeshwar, Bactericidal activity of $\mathrm{TiO}_{2}$ photocatalyst in aqueous media: toward a solar- assisted water disinfection system, Environmental Science and Technology, 28, (1994), 934-938.

[4]. X.Z. Li, M. Zhang, H. Chua, Disinfection of municipal wastewater by sensitized photooxidation, Water Science and Technology 33 (1996) 111118.

[5]. R.J. Watts, S. Kong, M. P. Orr, G. C. Miller, B. E. Henry, Photocatalytic inactivation of coliform bacteria and viruses in secondary wastewater effluent, Water Research 29 (1995) 95-100.

[6]. M. Bekbölet, Photocatalytic bactericidal activity of $\mathrm{TiO}_{2}$ in aqueous suspensions of E. Coli, Water Sci. Techn. 35 (1997) 95-100.

[7]. J. A. Herrera Melián, J. M. Doña Rodríguez, A. Viera Suárez, E. Tello Rendón, C. Valdés do Campo, J. Arana and J. Pérez Peña, The photocatalytic disinfection of urban waste waters. Chemosphere 41 (2000) 323-327.

[8]. J. Wist, J. Sanabria, C. Dierolf, W. Torres, C. Pulgarin, Evaluation of photocatalytic disinfection of crude water for drinking-water production, J. Photochem. Photobiol. A: Chemistry 147 (2002) 241-246. 
[9]. A-G. Rincón, C. Pulgarin, Effect of pH, inorganic ions, organic matter and $\mathrm{H}_{2} \mathrm{O}_{2}$ on $\mathrm{E}$. coli $\mathrm{K} 12$ photocatalytic inactivation by $\mathrm{TiO}_{2}$ : Implications in solar water disinfection, Applied Catalysis B: Environmental 51 (2004) 283-302.

[10]. J. M.C. Robertson, P. K. J. Robertson, L. A. Lawton, A comparison of the effectiveness of $\mathrm{TiO}_{2}$ photocatalysis and UVA photolysis for the destruction of three pathogenic micro-organisms, J. Photochem. Photobiol A: Chemistry 175 (2005) 51-56.

[11]. V.A. Nadtochenko, A.G. Rincon, S.E. Stanca, J. Kiwi, Dynamics of E. coli membrane cell peroxidation during $\mathrm{TiO}_{2}$ photocatalysis studied by ATR-FTIR spectroscopy and AFM microscopy, J. Photochem. Photobiol A: Chemistry 169 (2005) 131-137.

[12]. P. Fernández-I báñez, J. Blanco, C. Sichel, S. Malato, Water disinfection by solar photocatalysis using compound parabolic collectors, Catalysis Today 101 (2005) 345-352.

[13]. T. Saito, T. I wase, J. Horie, T. Morioka, Mode of photocatalytic bactericidal action of powdered semiconductor $\mathrm{TiO}_{2}$ on mutans streptococci, J. Photochem. Photobiol. B: Biology 14 369-379

[14]. P-C. Maness, S. Smolinski, D. M. Blake, Z. Huang, E. J. Wolfrum, W. A. J acoby, Bactericidal Activity of Photocatalytic $\mathrm{TiO}_{2}$ Reaction: toward an Understanding of Its Killing Mechanism, Applied and Environmental Microbiology, 65 (1999) 4094-4098.

[15]. Z. Huang, P-C. Maness, D.M. Blake, E.J. Wolfrum, S.L. Smolinski, W.A. Jacoby, Bactericidal mode of titanium dioxide photocatalysis, J. Photochem. Photobiol A : Chemistry 130 (2000) 163-170. 
[16]. Kayano Sunada, Toshiya Watanabe, Kazuhito Hashimoto, Studies on photokilling of bacteria on $\mathrm{TiO}_{2}$ thin film, J. Photochem. Photobiol. A: Chemistry 156 (2003) 227-233.

[17]. Y. Kikuchi, K. Sunada, T. Iyoda, K. Hashimoto, A. Fujishima, Photocatalytic bactericidal effect of $\mathrm{TiO}_{2}$ thin films: dynamic view of the active oxygen species responsible for the effect, J. Photochem. Photobiol. A: Chemistry 106 (1997) 51-56.

[18]. M. Suwalsky, C. Schneider, H.D. Mansilla J. Kiwi, Evidence for the hydration effect at the semiconductor phospholipid-bilayer interface by $\mathrm{TiO}_{2}$ photocatalysis, J. Photochem. Photobiol. B: Biology 78 (2005) 253258

[19]. P. Amézaga-Madrid, R. Silveyra-Morales, L. Córdoba-Fierro, G. V. Nevárez-Moorillón, M. Miki-Yoshida, E. Orrantia-Borunda, F. J. Solís, TEM evidence of ultrastructural alteration on Pseudomonas aeruginosa by photocatalytic $\mathrm{TiO}_{2}$ thin films, J. Photochem. Photobiol. B: Biology 70 (2003) 45-50.

[20]. World Health Organisation, Guidelines for drinking-water quality, Vol. 1, 3rd edition incorporating 1st and 2nd addenda, 2008.

[21]. C. Kittel Introduction to Solid State Physics $8^{\text {th }}$ Edition, 2005, John Wiley \& Sons Inc.

[22]. M. Litter. Heterogeneous photocatalysis transition metal ions in photocatalytic systems, Appl. Catal. B: Environ. 23 (1999) 89-114.

[23]. M. Litter, M. Morgada, M. Bundschuh, Possible treatments for arsenic removal in Latin American waters for human consumption, Environ. Poll. 
[24]. D. W. Bahnemann, M. Hildendorff, R. Memming, Charge carrier dynamics at $\mathrm{TiO}_{2}$ particles: reactivity of free and trapped holes, J. Phys. Chem. B 101 (1997) 4265-4275.

[25]. D. Monllor-Satoca, R. Gómez, M. González-Hidalgo, P. Salvador, The "Direct-Indirect" model: An alternative kinetic approach in heterogeneous photocatalysis based on the degree of interaction of disolved pollutant species with the semiconductor surface, Catal. Today 129 (2007) 247255.

[26]. P. Araujo, C. Mendive, L. García Rodenas, P. Morando, A. Regazzoni, M. Blesa, D.W. Bahnemann, FT-IR-ATR as a tool to probe photocatalytic interfaces, Coll. Surf. A: Physicochem. Eng. Asp. 265 (2005) 73-80.

[27]. A. Weisz, L. García Rodenas, P. Morando, A. Regazzoni, M. Blesa, Catal. Today, FTIR study of the adsorption of single pollutants and mixtures of pollutants onto titanium dioxide in water: oxalic and salicylic acids, 76 (2002) 103-112.

[28]. C.B. Mendive, T. Bredow, A. Feldhoff, M. Blesa, D.W. Bahnemann, Adsorption of oxalate on rutile particles in aquesous solutions: a spectroscopic, electron microscopic and theoretical study, Phys. Chem. Chem. Phys. 10 (2008) 1960-1974.

[29]. C.B. Mendive, T. Bredow, A. Feldhoff, M.A. Blesa, D.W. Bahnemann, Adsorption of oxalate on anatase (100) and rutile (110) surfaces in aquesous systems: experimental results vs. theoretical predictions, Phys. Chem. Chem. Phys. 11 (2009) 1794-1808. 
[30]. D.W. Bahnemann, D. Bockelmann, R. Goslich, Mechanistic studies of water detoxification in illuminated $\mathrm{TiO}_{2}$ suspensions, Sol. Ener. Mater. 24 (1991) 564-583.

[31]. C. Kormann, D.W. Bahnemann, M. R. Hoffmann, Photocatalytic production of $\mathrm{H}_{2} \mathrm{O}_{2}$ and organic peroxides in aqueous suspensions of $\mathrm{TiO}_{2}$, ZnO and desert sand, Environ. Sci. Technol. 22 (1988) 798-806

[32]. G. Waldner, R. Gómez, M. Neumann-Spallart, Using photoelectrochemical measurements for distinguishing between direct and indirect hole transfer processes on anatase: case of oxalic acid, Electrochim. Act. 52 (2007) 2634-263.

[33]. A.K. Benabbou, C. Guillard, S. Pigeot-Remy, C. Cantau, T. Pigot, P. Lejeune, Water disinfection using photosensitizers supported on silica, J. Photochem. Photobiol. A: Chemistry, 219 (2011) 101-108.

[34]. N. Baram, D. Starosvetsky, J. Starosvetsky, M. Epshtein, R. Armon, Y. Ein-Eli, Photocatalytic inactivation of microorganisms using nanotubular $\mathrm{TiO}_{2}$, Applied Catalysis B: Environmental 118 (2011) 212-219.

[35]. M. Lanao, M.P. Ormad, P. Goñi , N. Miguel, R. Mosteo, J.L. Ovelle, Inactivation of Clostridium perfringens spores and vegetative cells by photolysis and $\mathrm{TiO}_{2}$ photocatalysis with $\mathrm{H}_{2} \mathrm{O}_{2}$, Solar Energy 84 (2010) 703-709.

[36]. R. van Grieken, J. Marugán, C. Sordo, P. Martínez, C. Pablos, Photocatalytic inactivation of bacteria in water using suspended and immobilized silver- $\mathrm{TiO}_{2}$, Applied Catalysis B: Environmental 93 (2009) 112-118.

[37]. R. van Grieken, J. Marugán, C. Pablos, L. Furones, Ainhoa López, Comparison between the photocatalytic inactivation of Gram-positive $\mathrm{E}$. 
faecalis and Gram-negative E. coli faecal contamination indicator microorganisms, Applied Catalysis B: Environmental 100 (2010) 212-220.

[38]. A. Pal, S. O. Pehkonen, L.E. Yu, M.B.Ray, Photocatalytic inactivation of Gram-positive and Gram-negative bacteria using fluorescent light, J. Photochem. Photobiol. A: Chemistry 186 (2007) 335-341.

[39]. T.P. Cushnie, P. K.J. Robertson, S. Officer, P. M. Pollard, C. McCullagh, J. M.C. Robertson, Variables to be considered when assessing the photocatalytic destruction of bacterial pathogens, Chemosphere 74 (2009) 1374-1378.

[40]. G.K. Prasad, G.S. Agarwal, B. Singh, G.P. Rai, R. Vijayaraghavan, Photocatalytic inactivation of Bacillus anthracis by titania nanomaterials, J. Haz. Mat. 165 (2009) 506-510.

[41]. S. Pigeot-Rémy, F. Simonet, E. Errazuriz-Cerda, J.C. Lazzaroni, D. Atlan, C. Guillard, Photocatalysis and disinfection of water: Identification of potential bacterial targets, Applied Catalysis B: Environmental 104 (2011) 390-398.

[42]. R. van Grieken, J. Marugán, C. Sordo, C. Pablos, Comparison of the photocatalytic disinfection of E. coli suspensions in slurry, wall and fixedbed reactors, Catalysis Today 144 (2009) 48-54.

[43]. T.Y. Leung, C.Y. Chan, C. Hu, J.C. Yu, P.K. Wong, Photocatalytic disinfection of marine bacteria using fluorescent light, Water Research 42 (2008) 4827-4837.

[44]. L. Zan, W. Fa, T. Peng, Z-k.Gong, Photocatalysis effect of nanometer $\mathrm{TiO}_{2}$ and $\mathrm{TiO}_{2}$-coated ceramic plate on Hepatitis $\mathrm{B}$ virus, J. Photochem. Photobiol. B: Biology 86 (2007) 165-169.

[45]. C. Guillard, T-H. Bui, C. Felix, V. Moules, B. Lina, P. Lejeune, Microbiological disinfection of water and air by photocatalysis, Comptes 
Rendus Chimie 11 (2008) 107-113.

[46]. M. V. Liga, E. L. Bryantb, V. L. Colvinb, Q. Lia, Virus inactivation by silver doped titanium dioxide nanoparticles for drinking water treatment, Water Research 45 (2011) 535-544.

[47]. M. Cho, E. L. Cates, J-H. Kim, Inactivation and surface interactions of MS-2 bacteriophage in a $\mathrm{TiO}_{2}$ photoelectrocatalytic reactor, Water Research 45 (2011) 2104-2110.

[48]. C. Sichel, M. de Cara, J. Tello, J. Blanco, P. Fernández-Ibáñez, Solar photocatalytic disinfection of agricultural pathogenic fungi: Fusarium species, Applied Catal B: Environ. 74 (2007) 152-160.

[49]. C. Sichel, J. Tello, M. de Cara, P. Fernández-Ibáñez, Effect of UV solar intensity and dose on the photocatalytic disinfection of bacteria and fungi, Catalysis Today 129 (2007) 152-160.

[50]. P. Fernández-Ibáñez, C. Sichel, M.I. Polo-López, M. de Cara-García, J.C. Tello, Photocatalytic disinfection of natural well water contaminated by Fusarium solani using $\mathrm{TiO}_{2}$ slurry in solar CPC photo-reactors, Catalysis Today 144 (2009) 62-68.

[51]. S. Sontakke, Jayant Modak, G. Madras, Photocatalytic inactivation of Escherischia coli and Pichia pastoris with combustion synthesized titanium dioxide, Chem. Eng. Journal 165 (2010) 225-233.

[52]. D, Mitoraj, A. Jańczyk, M. Strus, H. Kisch, G. Stochel, P. B. Heczko, W. Macyk, Visible light inactivation of bacteria and fungi by modified titanium dioxide, Photochem. Photobiol. Sci. 6 (2007) 642-648.

[53]. M. Sokmen, S. Degerli, A. Aslan, Photocatalytic disinfection of Giardia intestinalis and Acanthamoeba castellani cysts in water, Experimental Parasitology 119 (2007) 44-48. 
[54]. H. Ryu, D. Gerrity, J.C. Crittenden, M. Abbaszadegan, Photocatalytic inactivation of Cryptosporidium parvum with $\mathrm{TiO}_{2}$ and low-pressure ultraviolet irradiation, Water Research 42 (2008) 1523-1530.

[55]. F. Méndez-Hermida, E. Ares-Mazás, K.G. McGuigan, M. Boyle, C. Sichel, P. Fernández-Ibáñez, Disinfection of drinking water contaminated with Cryptosporidium parvum oocysts under natural sunlight and using the photocatalyst $\mathrm{TiO}_{2}$. J. Photochem. Photobiol. B. 88 105-111, 2007

[56]. A. Paleologou, H. Marakas, N. P. Xekoukoulotakis, A. Moya, Y. Vergara, N. Kalogerakis, P. Gikas, D. Mantzavinos, Disinfection of water and wastewater by $\mathrm{TiO}_{2}$ photocatalysis, sonolysis and UV-C irradiation, Catalysis Today 129 (2007) 136-142.

[57]. A.K. Benabbou, Z. Derriche, C. Felix, P. Lejeune, C. Guillard Photocatalytic inactivation of Escherischia coli: Effect of concentration of $\mathrm{TiO}_{2}$ and microorganism, nature, and intensity of UV irradiation, Applied Catalysis B: Environmental 76 (2007) 257-263.

[58]. L. Rizzo, Inactivation and injury of total coliform bacteria after primary disinfection of drinking water by $\mathrm{TiO}_{2}$ photocatalysis, J. Haz. Mat., 165 (2009) 48-51.

[59]. N. Lydakis-Simantiris, D. Riga, E. Katsivela, D. Mantzavinos, N. P. Xekoukoulotakis, Disinfection of spring water and secondary treated municipal wastewater by $\mathrm{TiO}_{2}$ photocatalysis, Desalination 250 (2010) 351-355.

[60]. J. Marugan, R. van Grieken, C. Pablos, C. Sordo, Analogies and differences between photocatalytic oxidation of chemicals and photocatalytic inactivation of microorganisms, Water Research 44 (2010) 789-796.

[61]. S. Malato, P. Fernández-Ibáñez, M.I. Maldonado, J. Blanco, W. Gernjak, 
Decontamination and disinfection of water by solar photocatalysis: Recent overview and trends, Catalysis Today 147 (2009) 1-59.

[62]. A-G. Rincón, C. Pulgarin, Use of coaxial photocatalytic reactor (CAPHORE) in the $\mathrm{TiO}_{2}$ photo-assisted treatment of mixed E-coli and Bacillus sp and bacterial community present in wastewater, Catalysis Today, (2005) 331-344.

[63]. P.S.M. Dunlop, T.A. McMurray, J.W.J. Hamilton, J. A. Byrne, Photocatalytic inactivation of Clostridium perfringens spores on $\mathrm{TiO}_{2}$ electrodes, Journal of Photochemistry and Photobiology A: Chemistry 196 (2008) 113-119.

[64]. S. M. Zacarías, M. C. Vaccari, O.M. Alfano, H.O. Irazoqui, G. E. Imoberdorf, Effect of the radiation flux on the photocatalytic inactivation of spores of Bacillus subtilis, J. Photochem. Photobiol. A: Chemistry 214 (2010) 171-180.

[65]. M.I. Polo-López, I. García-Fernández, I. Oller, P. Fernández-I báñez. Solar disinfection of fungal spores in water aided by low concentrations of hydrogen peroxide, Photochem. Photobiol. Sci., 10, 381-388, 2011.

[66]. C. Pablos, R. van Grieken, J. Marugán, B. Moreno, Photocatalytic inactivation of bacteriar in a fixed-bed reactor: Mechanistic insights by epifluorescence microscopy, Catalysis Today, 161, 133-139, 2011

[67]. P. Wu, R. Xie, J. A. Imlay, J. K. Shang, Visible-light-induced photocatalytic inactivation of bacteria by composite photocatalysts of palladium oxide and nitrogen-doped titanium oxide, Applied Catalysis B: Environmental 88 (2009) 576-581.

[68]. S. Pigeot-Rémy, F. Simonet, E. Errazuriz-Cerda, J.C. Lazzaroni, D. Atlan and C. Guillard Photocatalysis and disinfection of water: Identification of potential bacterial targets, Applied Catalysis B: 
Environmental 104 (2011) 390-398.

[69]. Y. Li, M. Ma, X. Wang, X. Wang, Inactivated properties of activated carbon-supported $\mathrm{TiO}_{2}$ nanoparticles for bacteria and kinetic study, J ournal of Environmental Sciences 20 (2008) 1527-1533.

[70]. F. Goulhen-Chollet, S. Josset, N. Keller, V. Keller, M-C. Lett, Monitoring the bactericidal effect of UV-A photocatalysis: A first approach through 1D and 2D protein electrophoresis, Catalysis Today 147 (2009) 169-172.

[71]. A.G. Rincón, C. Pulgarín, Solar Photolytic and Photocatalytic Disinfection of Water at Laboratory and Field Scale. Effect of the Chemical Composition of Water and Study of the Postirradiation Events, J. Sol. Energy Eng. 129 (2007) 100-110.

[72]. D.M.A. Alrousan, P.S.M. Dunlop, T.A. McMurray, J.A. Byrne, Photocatalytic inactivation of E. coli in surface water using immobilised nanoparticle $\mathrm{TiO}_{2}$ films, Water Research 43 (2009) 47-54.

[73]. M. N. Chong, B. Jin, H. Zhu, C. Saint, Bacterial inactivation kinetics, regrowth and synergistic competition in a photocatalytic disinfection system using anatase titanate nanofiber catalyst, J. Photochem. Photobiol.A:Chemistry 214 (2010) 1-9.

[74]. A.G.Rincón, C. Pulgarin, $\mathrm{Fe}^{3+}$ and $\mathrm{TiO}_{2}$ solar-light-assisted inactivation of E. coli at field scale: Implications in solar disinfection at low temperature of large quantities of water, Catalysis Today 122 (2007) 128136.

[75]. A.G. Rincón, C. Pulgarin, Absence of E. coli regrowth after $\mathrm{Fe}^{3+}$ and $\mathrm{TiO}_{2}$ solar photoassisted disinfection of water in CPC solar photoreactor, Catalysis Today 124 (2007) 204-214.

[76]. N. Baram, D. Starosvetsky, J.Starosvetsky, M. Epshtein, R. Armon Y. Ein-Eli, Photocatalytic inactivation of microorganisms using nanotubular 
$\mathrm{TiO}_{2}$, Applied Catalysis B: Environmental 101 (2011) 212-219.

[77]. A. Bernabeu, R.F. Vercher, L. Santos-Juanes, P.J. Simón, C. Lardín, M.A. Martínez, J.A. Vicente, R. González, C. Llosá, A. Arques, A.M. Amat, Solar photocatalysis as a tertiary treatment to remove emerging pollutants from wastewater treatment plant effluents, Catalysis Today 161 (2011) 235-240.

[78]. A.I.Gomes, J.C. Santos, V.J.P. Vilar, Rui A.R. Boaventura, Inactivation of Bacteria E. coli and photodegradation of humic acids using natural sunlight, Applied Catalysis B: Environmental 88 (2009) 283-291.

[79]. R.van Grieken, J. Marugán, C. Sordo, Cristina Pablos, Comparison of the photocatalytic disinfection of E. coli suspensions in slurry, wall and fixed-bed reactors, Catalysis Today, 144 (2009) 48-54.

[80]. C. Pablos, R. van Grieken, J. Marugán, B. Moreno, Photocatalytic inactivation of bacteria in a fixed-bed reactor: Mechanistic insights by epifluorescence microscopy, Catalysis Today 161 (2011) 133-139.

[81]. M. Subrahmanyam, P. Boule, V. Durga Kumari, D. Naveen Kumar, M. Sancelme, A. Rachel, Pumice stone supported titanium dioxide for removal of pathogen in drinking water and recalcitrant in wastewater, Solar Energy 82 (2008) 1099-1106.

[82]. C. Sordo, R. van Grieken, J. Marugán, P. Fernández-Ibáñez, Solar photocatalytic disinfection with immobilised $\mathrm{TiO}(2)$ at pilot-plant scale, Wat. Sci. Tech., 61 (2010) 507-512.

[83]. J.A. Rengifo-Herrera, J. Kiwi, C. Pulgarin, N, S co-doped and N-doped Degussa P-25 powders with visible light response prepared by mechanical mixing of thiourea and urea. Reactivity towards E. coli inactivation and phenol oxidation, Journal of Photochemistry and Photobiology A: Chemistry 205 (2009) 109-115. 
[84]. C. Karunakaran, G. Abiramasundari, P. Gomathisankar, G. Manikandan, V. Anandi, Cu-doped $\mathrm{TiO}_{2}$ nanoparticles for photocatalytic disinfection of bacteria under visible light, J ournal of Colloid and Interface Science 352 (2010) 68-74.

[85]. Q. Li, Y. W. Li, Z. Liu, R. Xie and J. K. Shang, Memory antibacterial effect from photoelectron transfer between nanoparticles and visible light photocatalyst, J. Mater. Chem., 20, 2010, 1068-1072.

[86]. L. R. Quisenberry, L. H. Loetscher, J.E. Boyd, Catalytic inactivation of bacteria using Pd-modified titania, Catalysis Communications 10 (2009) 1417-1422.

[87]. K. Kowal, K. Wysocka-Król, M Kopaczyńska, E. Dworniczek, R. Franiczek, M. Wawrzyńska, M, Vargová, M, Zahoran, E. Rakovský, P. Kuš, G. Plesch, A. Plecenik, F. Laffir, S.A. Tofail, H. Podbielska, In situ photoexcitation of silver-doped titania nanopowders for activity against bacteria and yeasts, J Colloid Interface Sci. 362 (2011) 50-57.

[88]. N. Baram, D. Starosvetsky, J. Starosvetsky, M. Epshtein, R. Armon, Y. Ein-Eli, Enhanced photo-efficiency of immobilized $\mathrm{TiO}_{2}$ catalyst via intense anodic bias, Electrochemistry Communications, 9 (2007) 1684-1688.

[89]. N. Baram, D. Starosvetsky, J.Starosvetsky, M. Epshtein, R. Armon Y. Ein-Eli, Enhanced inactivation of E. coli bacteria using immobilized porous $\mathrm{TiO}_{2}$ photoelectrocatalysis, Electrochimica Acta 54 (2009) 3381-3386.

[90]. J.C. Harper, P.A. Christensen, T.A. Egerton, T.P. Curti, J. Gunlazuardi, Effect of catalyst type on the kinetics of the photoelectrochemical disinfection of water inoculated with E. coli, J. App. Electrochem, 31 (2001) 623-628

[91]. G. Li, X. Liu, H. Zhang, T. An, S. Zhang, A. R. Carroll, H. Zhao, In situ 
photoelectrocatalytic generation of bactericide for instant inactivation and rapid decomposition of Gram-negative bacteria, Journal of Catalysis 277 (2011) 88-94.

[92]. W.W. Carmichael, The Cyanotoxins. Adv. Bot. Res. 27 (1997) 211256.

[93]. K. Sivonen Cyanobacterial toxins and toxin production. Phycologia 35 (1996) 12-24 .

[94]. S-Z. Yu, Blue-green algae and liver cancer, in Toxic Cyanobacteria: Current Status of Research and Management, Steffensen, D. A, Nicholson, B. C. Eds; Australia Centre for Water Quality Research: Salisbury,. Australia, 1994.

[95]. C.Mackintosh, K.A. Beattie, S. Klumpp, P.Cohen and G.A.Godd, Cyanobacterial microcystin-LR is a potent and specific inhibitor of protein phosphatases 1 and 2A from both mammals and higher plants, FEBS Lett. 264 (1990)187-192.

[96]. A. A. de la Cruz, M. Antoniou, A. Hiskia, M. Pelaez, W. Song, K. E. O'Shea, X. He, D.D. Dionysiou, Can we effectively degrade microcystins?Implications on human health, Anti-Cancer Agents in Medicinal Chemistry, 11 (2011) 19-37.

[97]. W. W. Carmichael, S.M.F.O. Azevedo, J.S. An, R.J. R. Molica, E. M. J ochimsen, S.Lau, K. L. Rinehart, G. R. Shaw, G. K. Eaglesham, Human Fatalities from Cyanobacteria: Chemical and Biological Evidence for Cyanotoxins, Environmental Health Perspectives, 109, ( 2001) 663-668 
[98]. K. Lahti, L. Hiisvirta, Removal of cyanobacterial toxins in water treatment processes: review of studies conducted in Finland, Water Supply and Management, 7 (1989) 149-154.

[99]. A. M. Keijola, K. Himberg, A. L. Esala, K. Sivonen, L. Hiisvirta, Removal of cyanobacterial toxins in water treatment processes: laboratory and pilot-scale experiments. Toxicol. Assess. 3 (1988) 643656.

[100]. L.A. Lawton and P. K.J. Robertson, Physico-chemical methods for the removal of Microcystins, Chem. Soc. Rev., 1999, 28, 217-225.

[101].P.K.J. Robertson, L.A. Lawton, B. Munch, J. Rouzade, Destruction of cyanobacterial toxins by semiconductor photocatalysis. Chem. Commun. (1997) 393-394.

[102].P.K.J. Robertson, L. A. Lawton, B. Münch and B. J.P.A. Cornish, The Destruction of Cyanobacterial Toxins by $\mathrm{TiO}_{2}$ Photocatalysis, J. Adv. Oxid. Technol., 4 (1999) 20-26.

[103].P.K.J . Robertson, L.A. Lawton, B.J.P.A. Cornish, M. Jaspars, Processes Influencing the Destruction of Microcystin-LR by $\mathrm{TiO}_{2}$ Photocatalysis, J . Photochem, Photobiol,A, Chem. 116 (1998) 215-219.

[104]. L.A. Lawton, P.K.J. Robertson, B.J.P.A. Cornish, M. Jaspars, Detoxification Microcystins (cyanobacterial hepatotoxins) using $\mathrm{TiO}_{2}$ Photocatalytic Oxidation, Environ. Sci. Technol.. 33 (1999) 771-775.

[105].I. Liu, L.A. Lawton, B.J.P.A Cornish, P.K.J. Robertson, Mechanistic and toxicity studies of the photocatalytic oxidation of microcystin-LR, J. Photochem, Photobiol, A, Chem, 148 (2002) 349-354. 
[106].M.G. Antoniou, P.A. Nicolaou, J.A. Shoemaker, A.A de la Cruz and D.D. Dionysiou, Impact of the morphological properties of thin $\mathrm{TiO}_{2}$ photocatalytic films on the detoxification of water contaminated with the cyanotoxin, microcystin-LR, App. Catl. B: Environ., 91 (2009) 165-173.

[107].I. Liu, L.A. Lawton, P. K. J. Robertson, Mechanistic studies of the photocatalytic oxidation of microcystin-LR: An investigation of byproducts of the decomposition process, Env. Sci. Technol. 37 (2003) 3214-3219.

[108]. W.H. Song, S. Bardowell, K O'Shea, Mechanistic study and the influence of oxygen on the photosensitized transformations of microcystins (Cyanotoxins), Environ. Sci. Technol. 41 (2007) 5336-5341

[109]. M. G. Antoniou, J. A. Shoemaker, A. A. de la Cruz, D. D. Dionysiou, Unveiling New Degradation Intermediates/Pathways from the Photocatalytic Degradation of Microcystin-LR, Environ. Sci. Technol. 42, (2008) 8877-8883

[110].M.G. Antoniou, J.A. Shoemaker, A.A de la Cruz and D.D. Dionysiou, LC/MS/MS structure elucidation of reaction intermediates formed during the $\mathrm{TiO}_{2}$ photocatalysis of microcystin-LR, Toxicon, 51 (2008) 1103-1118.

[111].G. S. Shepard, S. Stockenstrom, D. De Villiers, W. J. Engelbrecht, E.W. Sydenham and G. F. S. Wessels, Photocatalytic degradation of cyanobacterial microcystin toxins in water, Toxicon, 36 (1998) 1895-1901.

[112]. A. J. Feitz, T.D. Waite, G.J . Jones, B.H. Boyden, P.T. Orr, Photocatalytic degradation of the blue green algal toxin microcystin-LR in a natural organic-aqueous matrix. Environ. Sci. Technol. 33 (1999) 243249. 
[113]. L.A. Lawton, P.K.J. Robertson, B.J .P.A. Cornish, I.L. Marr, M. Jaspars, Processes influencing surface interaction and photocatalytic destruction of microcystins on titanium dioxide photocatalysts, J. Catal., 213 (2003) 109-113.

[114].B.J.P.A. Cornish, P.K.J . Robertson, L.A. Lawton, Hydrogen Peroxide Enhanced Photocatalytic Destruction of Microcystin-LR, Appl. Catal. B, Environ. 25 (2000) 59-67.

[115]. B. Yuan, Y. Li, X. Huang, H. Liu and J. Qu, Fe(VI)-assisted photocatalytic degradating of microcystin-LR using titanium dioxide, J . Photochem. Photobiol. A: Chem. 178 (2006) 106-111.

[116].I. Liu, L.A. Lawton, D.W. Bahnemann, B. Proft, P.K.J. Robertson, The photocatalytic decomposition of microcystin-LR using selected titanium dioxide materials. Chemosphere 76 (2009) 549-553.

[117].H. Choi, M.G. Antoniou, M. Pelaez, A.A. De la Cruz, J.A., Shoemaker, D.D. Dionysiou, Mesoporous nitrogen-doped $\mathrm{TiO}_{2}$ for the photocatalytic destruction of the cyanobacterial toxin microcystin-LR under visible light irradiation. Environ. Sci. Technol. 41, (2007) 7530-7535.

[118]. M. Pelaez, P. Falaras, V. Likodimos, A.G. Kontos, A.A. de la Cruz, K. Oshea and D.D. Dionysiou, Synthesis, structural characterisation and evaluation of sol-gel-based NF-TiO2 films with visible light photoactivation for the removal of microcystin-LR, App. Catal. B: Environ, 99 (2010) 378387.

[119]. D. Graham, H. Kisch, L.A. Lawton, P.K.J. Robertson, The degradation of microcystin-LR using doped visible light absorbing photocatalysts, Chemosphere 78 (2010) 1182-1185. 
[120]. M. Pelaez, A.A. de la Cruz, K. O'Shea, P. Falaras, D.D. Dionysiou, Effects of water parameters on the degradation of microcystin-LR under visible light-activated $\mathrm{TiO}_{2}$ photocatalyst, Wat. Res. 45 (2011) 3787-3796.

[121].P.K.J . Robertson, L.A. Lawton, B.J.P.A. Cornish The Involvement of Phycocyanin Pigment in the Photo-oxidation of the Cyanobacterial Toxin Microcystin-LR, J ournal of Porphyrins and Phthalocyanines, 3 (1999) 544551.

[122].I. Liu, L.A. Lawton, D.W. Bahnemann, B. P.K.J. Robertson, A mechanistic study of the photocatalytic destruction of nodularin using $\mathrm{TiO}_{2}$, Appl. Catal. B, Environ., 60 (2005) 245-252.

[123].P.J. Senogles, J.A. Scott, G. Shaw, H. Stratton, Photocatalytic degradation of the cyanotoxin cylindrospermopsin, using titanium dioxide and UV irradiation, Wat. Res. 35 (2001) 1245-1255.

[124].S.C Kim, D.K. Lee, Inactivation of algal blooms in eutrophic water of drinking water supplies with the photocatalysis of $\mathrm{TiO}_{2}$ thin film on hollow glass beads, Water Sci. Technol. 52 (2005) 145-52.

[125]. Linda A. Lawton, Peter K.J . Robertson, Russell F. Robertson, Fiona G. Bruce, The destruction of 2-methylisoborneol and geosmin using titanium dioxide photocatalysis, Applied Catalysis B: Environmental 44 (2003) 913.

[126].E. Bellu, L. A. Lawton, and P.K. J. Robertson, "Photocatalytic Destruction of Geosmin Using Novel Pelleted Titanium Dioxide", J ournal of Advanced Oxidation Technologies, 11 (2008) 384-388 
[127].P.K.J. Robertson, D.W. Bahnemann, E. Bellu and L. A. Lawton and "A study of the kinetic isotope effect on the photocatalytic destruction of geosmin", App. Catal. B: Environ., 108-109 (2011) 1-5.

[128].S.J. Yoon, Y. H. Lee, W.J. Cho, I.O. Koh, M. Yoon, Synthesis of $\mathrm{TiO}_{2-}$ entrapped EFAL-removed Y-zeolites: Novel photocatalyst for decomposition of 2-methylisoborneol, Catalysis Communications 8(2007) 1851-1856.

[129].Y. Djaoud, M. Thibodeau, J. Robichaud, S. Balaji, S. Priya, N. Tchoukanova, S.S. Bates, Photocatalytic degradation of domoic acid using nanocrystalline $\mathrm{TiO}_{2}$ thin films, J. Photochem. Photobiol. A. Chem., 193 (2008) 271-283.

[130].Y. Tominaga, T. Kubo, K. Hosoya, Surface modification of $\mathrm{TiO}_{2}$ for selective photodegradation of toxic compounds, Catal. Commun., 12 (2011) 785-789.

[131]. U. Khan, N. Benabderrazik, A.J. Bourdelais, D.G. Baden, K. Reid, P.R. Gardinali, L. Arroyo, K. E. O'Shea, UV and solar photocatalysis of brevetoxins (PbTxs), Toxicon 55 (2010) 1008-1016. 
Figure. 1 TEM pictures of E. coli cells in suspension in water exposed to UV-A photocatalysis with TiO2 P-25 $(0.25 \mathrm{~g} / \mathrm{I})$ and IUV-A $=3.45 \mathrm{~mW} / \mathrm{cm} 2:(\mathrm{a})$ after 80 min of exposure, (b) and (c) after 180 min of exposure. (Reproduced from 41 with kind permission of Elsevier).

Figure 2. Evolution of E. coli in the dark after solar disinfection: without catalyst, experiment of September 20th (a), $\mathrm{TiO}_{2} /$ sunlight system experiment of September 15th (d), (Reproduced from 75 with kind permission of Elsevier).

Figure 3. Effect of the cumulative solar UV dose (bars with diagonal fill) and hourly average solar UV irradiance (solid bars) on the photocatalytic inactivation of F.solani under natural solar radiation with $(\bullet, 0)$ and without $\mathrm{TiO}_{2}(\boldsymbol{\square}, \square)$. Experiments started at 08:30 (a) and at 10:15 (b). I nitial concentration of $\mathrm{F}$. solani $1.3 \times 10^{3} \mathrm{CFU} / \mathrm{mL}$. Each point represents the average of triplicates, and vertical lines show the statistical error at 95\% confidence level. (Reproduced from 49 with kind permission of Elsevier)

Figure 4. Photocatalytic E. coli inactivation under visible light irradiation. (•) Pure Degussa P-25, (A) pure Degussa P-25 annealed at $400 \circ \mathrm{C},(\diamond) \mathrm{N}, \mathrm{S}$ codoped P-25 and ( - ) N-doped P-25, ( $\times$ ) visible light exposure without catalyst. $\mathrm{pH} 7.0, \mathrm{UV}$ intensity $0.1 \mathrm{Wm}^{-2}$ and visible light intensity: $60 \mathrm{Wm}^{-2}$ (Reproduced from 83 with kind permission of Elsevier). 
Figure 5. Generic structure of microcystins where $\mathrm{X}$ and $\mathrm{Z}$ represent the variable amino acids and, D-Me-Asp is D-erythro- $\beta$-methylaspartic acid, Adda is(2S, 3S, 8S, 9S)-3-amino-9-methoxy-2,6,8-trimethyl-10-phenyldeca4(E),6(E)-dienoic acid, D-Glu is D-glutamic acid and Mdha is N-Medehydroalanine. (reproduced with permission from Environ. Sci. Technol. 37 (2003) 3215-3219. Copyright 2003 American Chemical Society).

Figure 6. The photocatalytic destruction of microcystin- $\mathrm{LR}$ in $\mathrm{H}_{2} \mathrm{O}$ and $\mathrm{D}_{2} \mathrm{O}$ solvents (Reproduced from 103 with kind permission of Elsevier)

Figure 7. Destruction and PP1 inhibition of microcystin-LR (photocatalysis with $\mathrm{TiO}_{2}$ ). Each point plotted for PP1 inhibition is the mean of 3 observations. The concentration of PP1 in the test was $4 \mu \mathrm{g} \mathrm{mL}^{-1}$. (reproduced from 105 with kind permission from Elsevier).

Figure. 8. Destruction of microcystin-LR by $\mathrm{TiO}_{2}$ photocatalysis with $(\diamond) 0.1 \%$ $\mathrm{H}_{2} \mathrm{O}_{2}$ and $(\square) 0.01 \% \mathrm{H}_{2} \mathrm{O}_{2}$. B corresponds to the toxin concentration before $\mathrm{TiO}_{2}$ was added to the system. Levels monitored by HPLC, bars are equivalent to $1 \mathrm{SD}(\mathrm{nD2})$. (reproduced from 114 with kind permission from Elsevier). 
Figure 9. The photocatalytic degradation of Microcystin-LR on $\mathrm{TiO}_{2}(\mathrm{P} 25$, PC50, PC500 and UV100) over 100 min irradiation times (reproduced from 116 with kind permission from Elsevier).

Table 1. Range of micororganisms removed from water using semiconductor photocatalysis.

Table 2. Range of cyanobacterial metabolites removed from water using semiconductor photocatalysis 

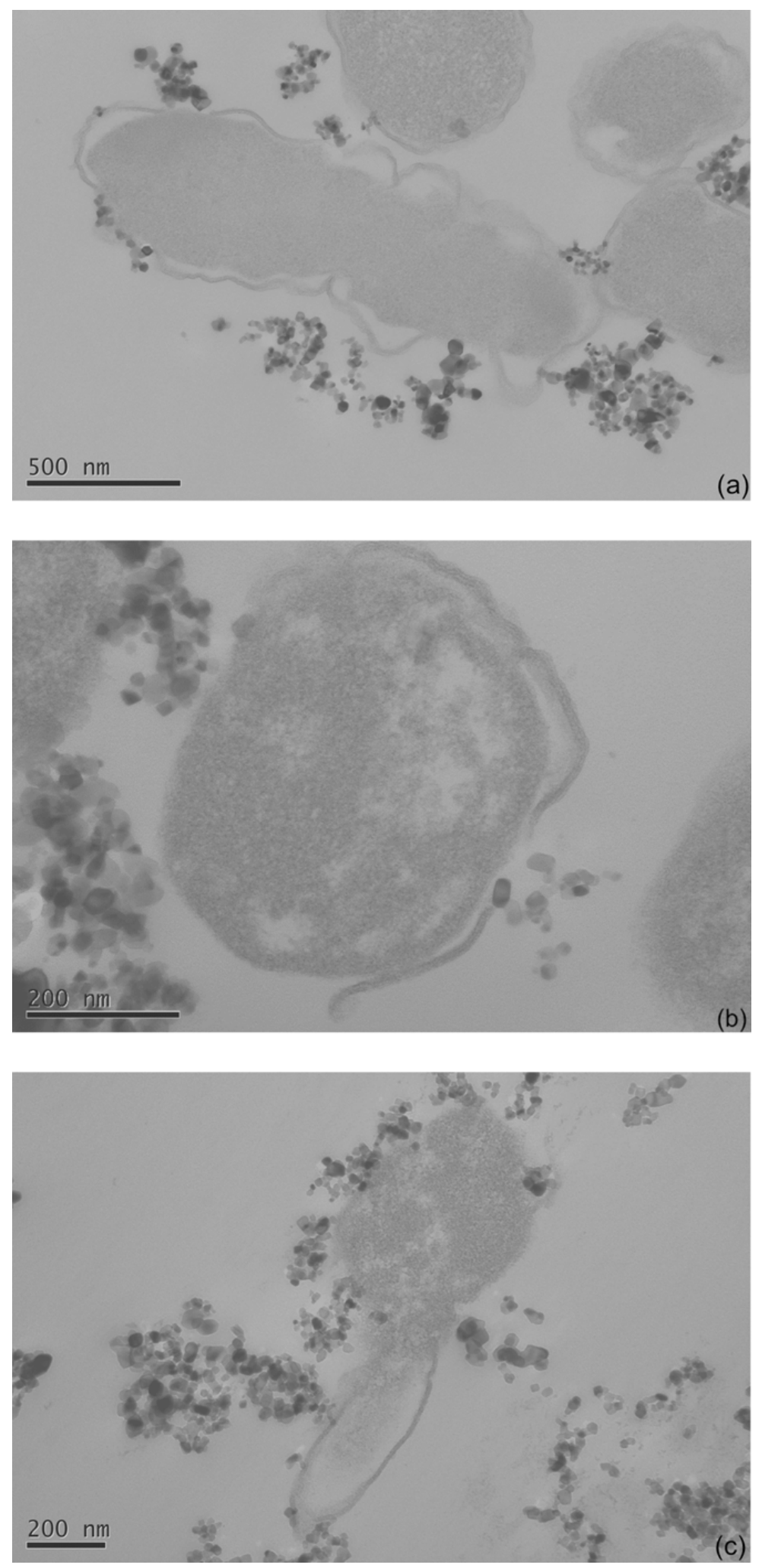

Figure 1 


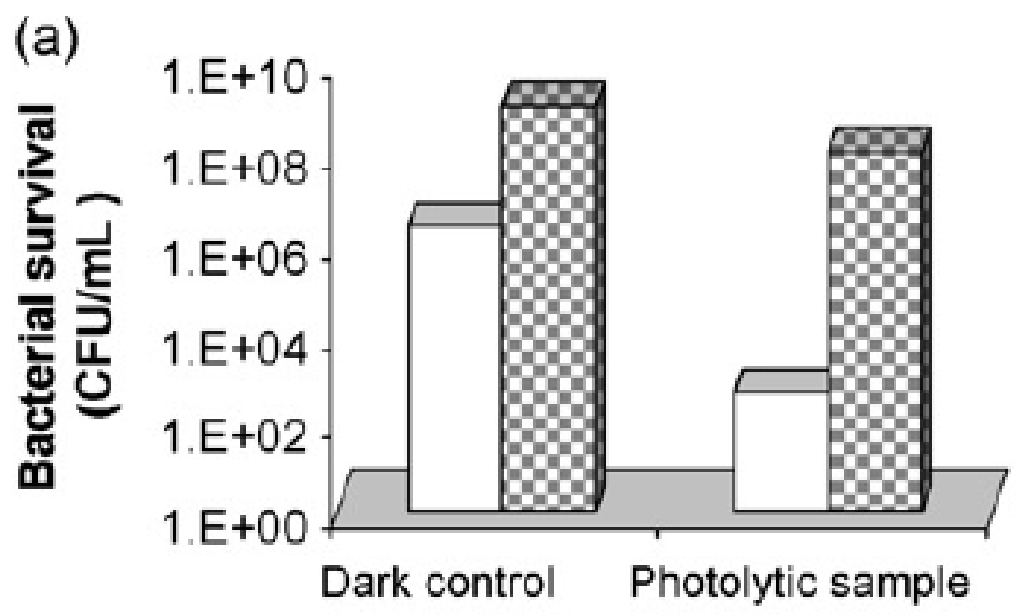

(d)

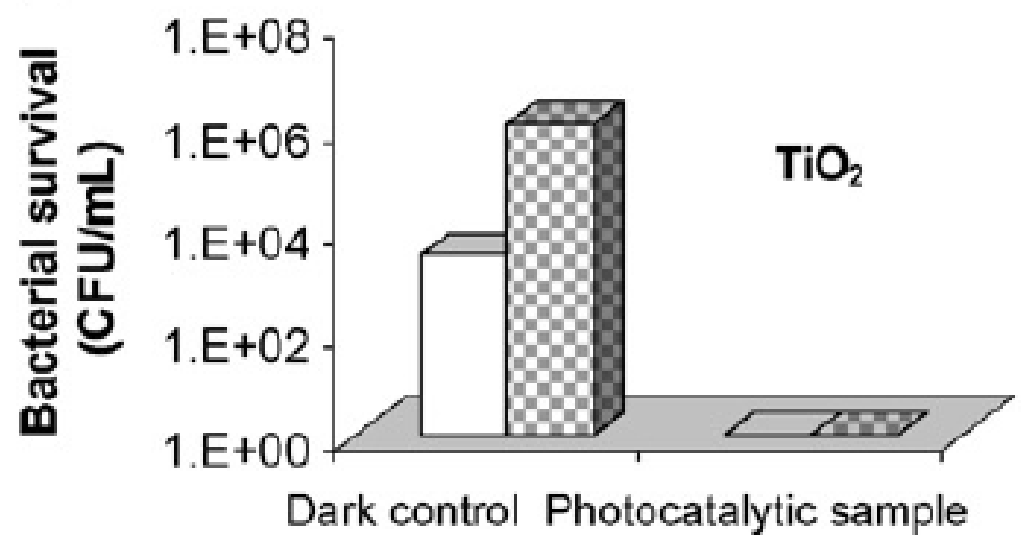

Figure 2. 

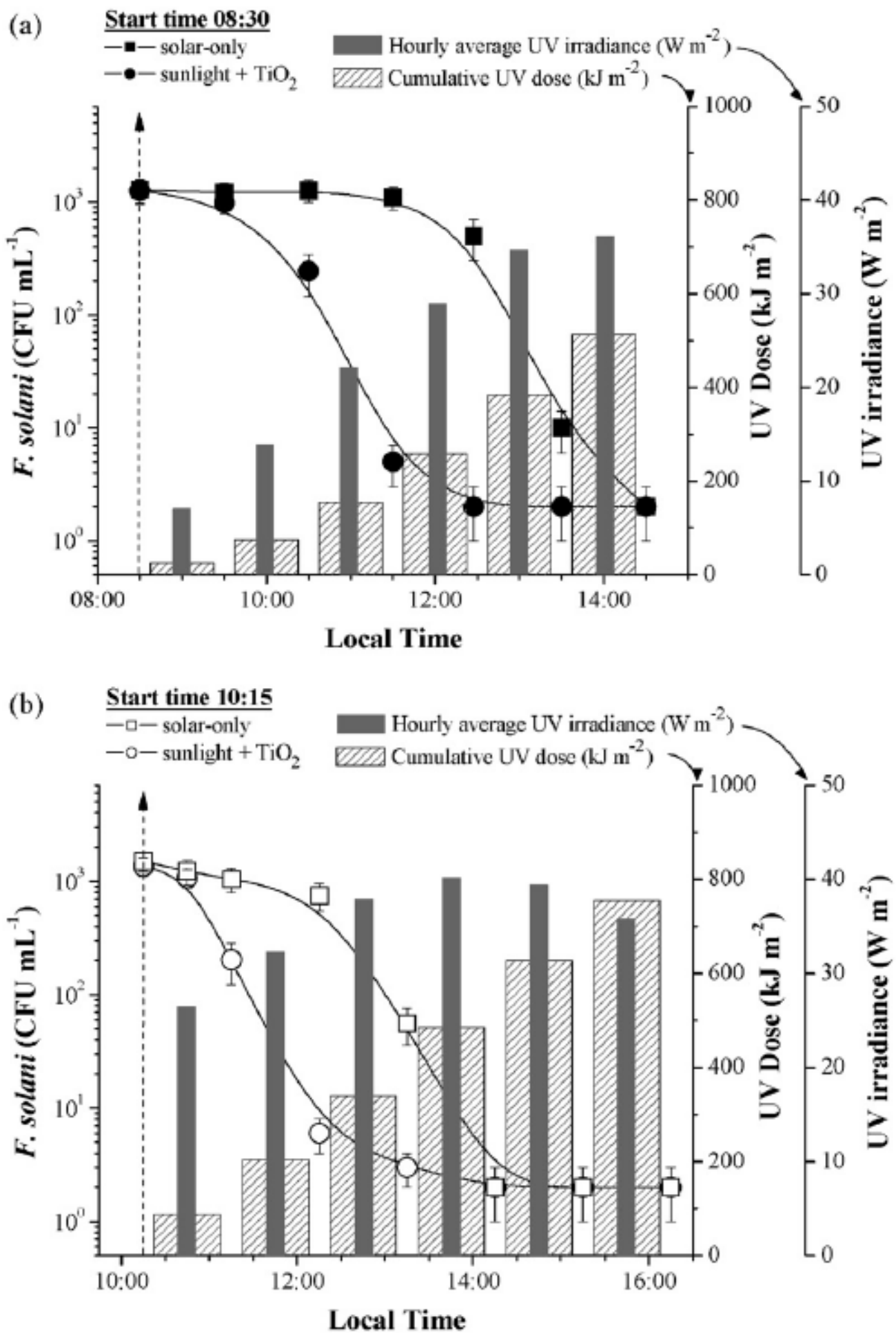

Figure 3. 


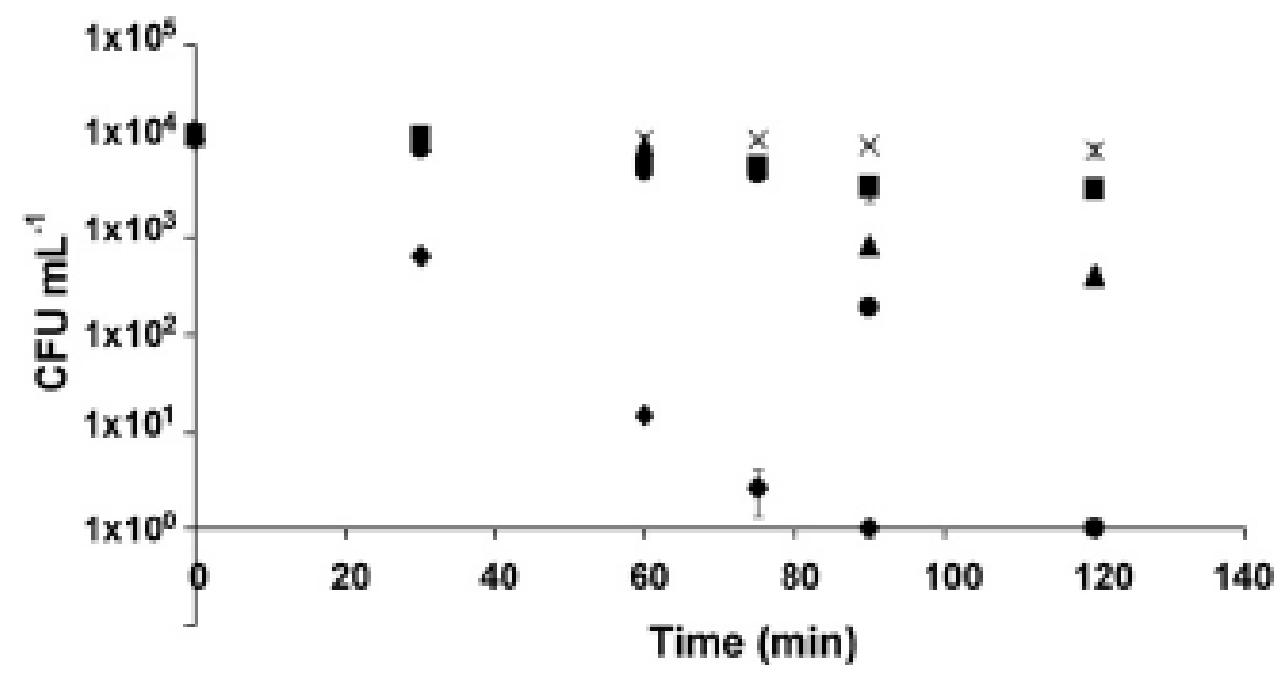

Figure 4 .

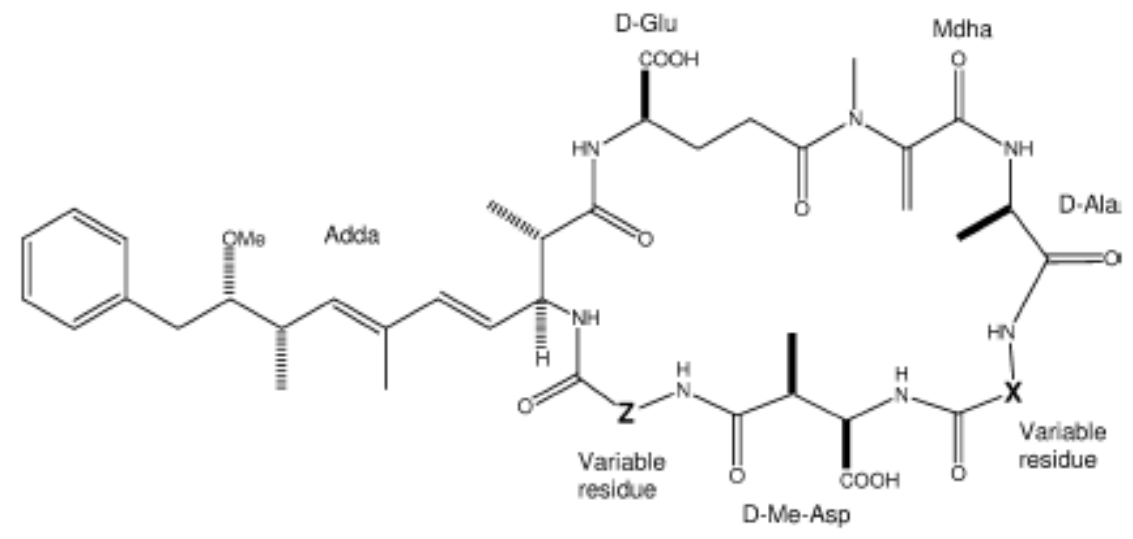

Figure 5 


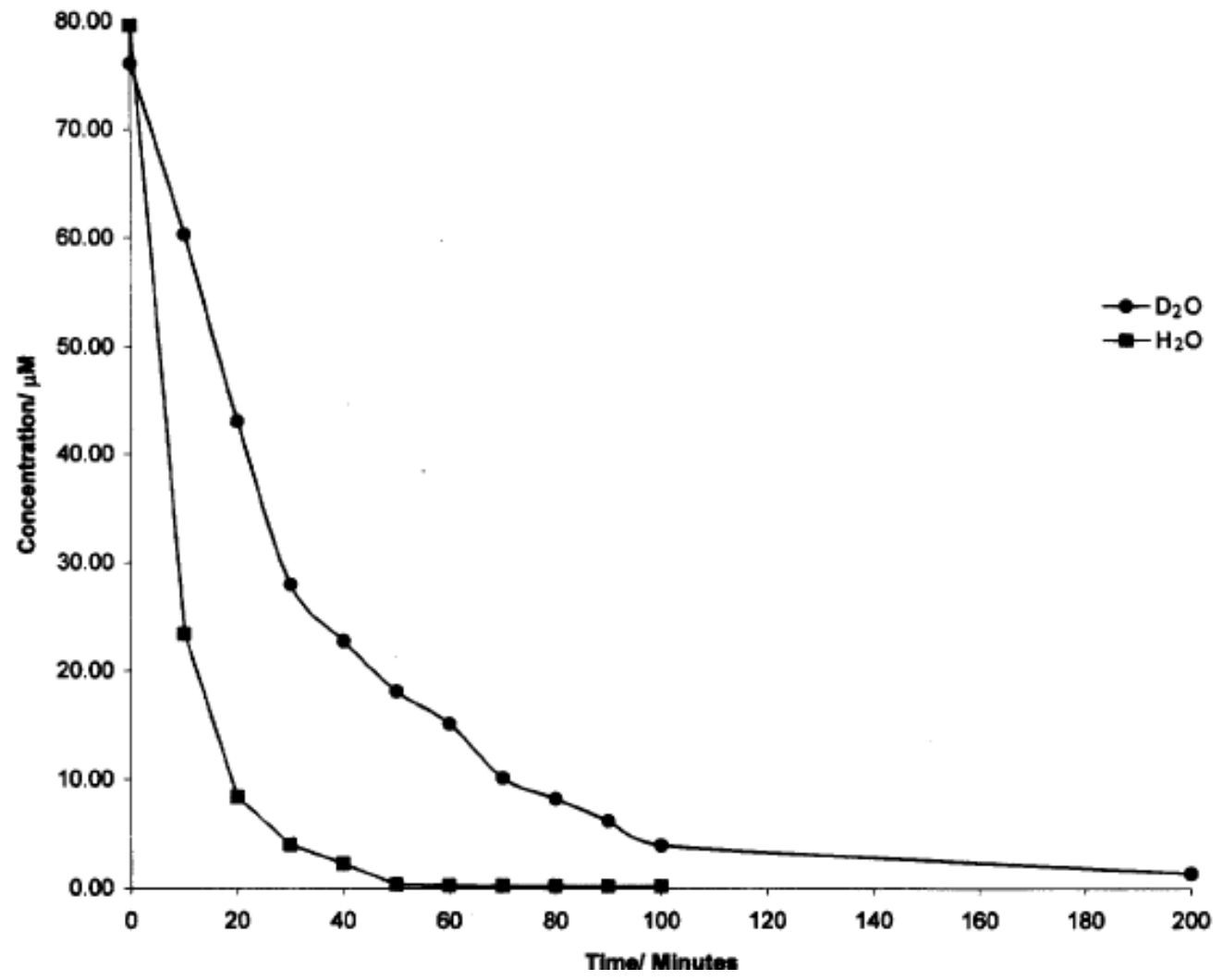

Figure 6. 


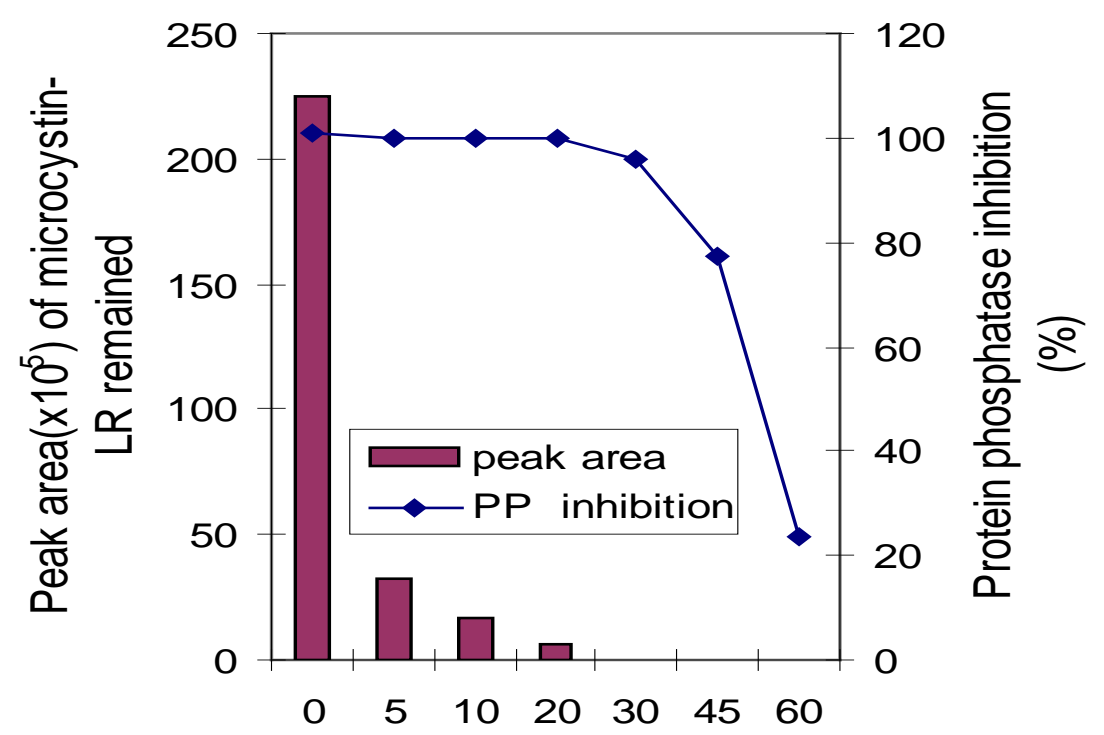

Time in minutes for photocatalysis

Figure 7 


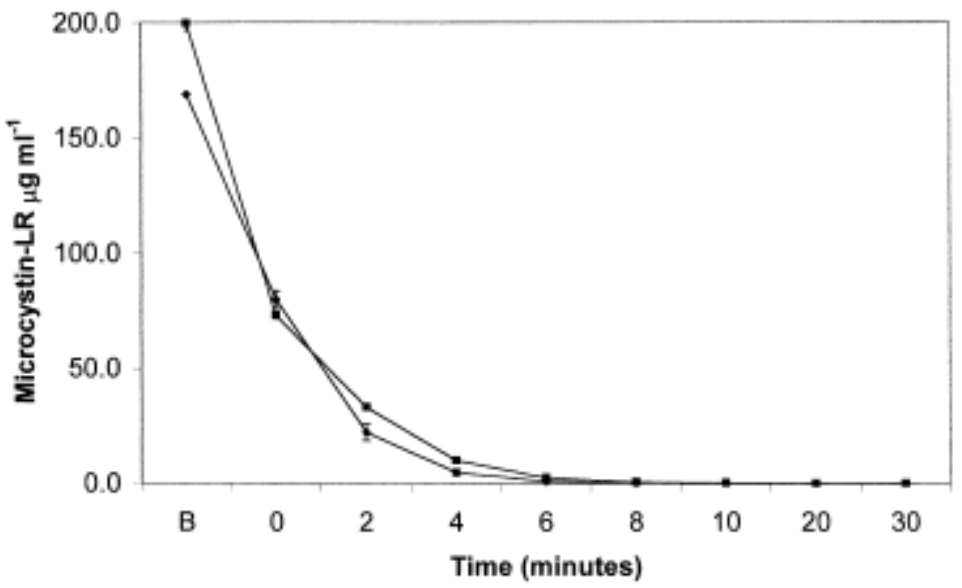

Figure 8. 


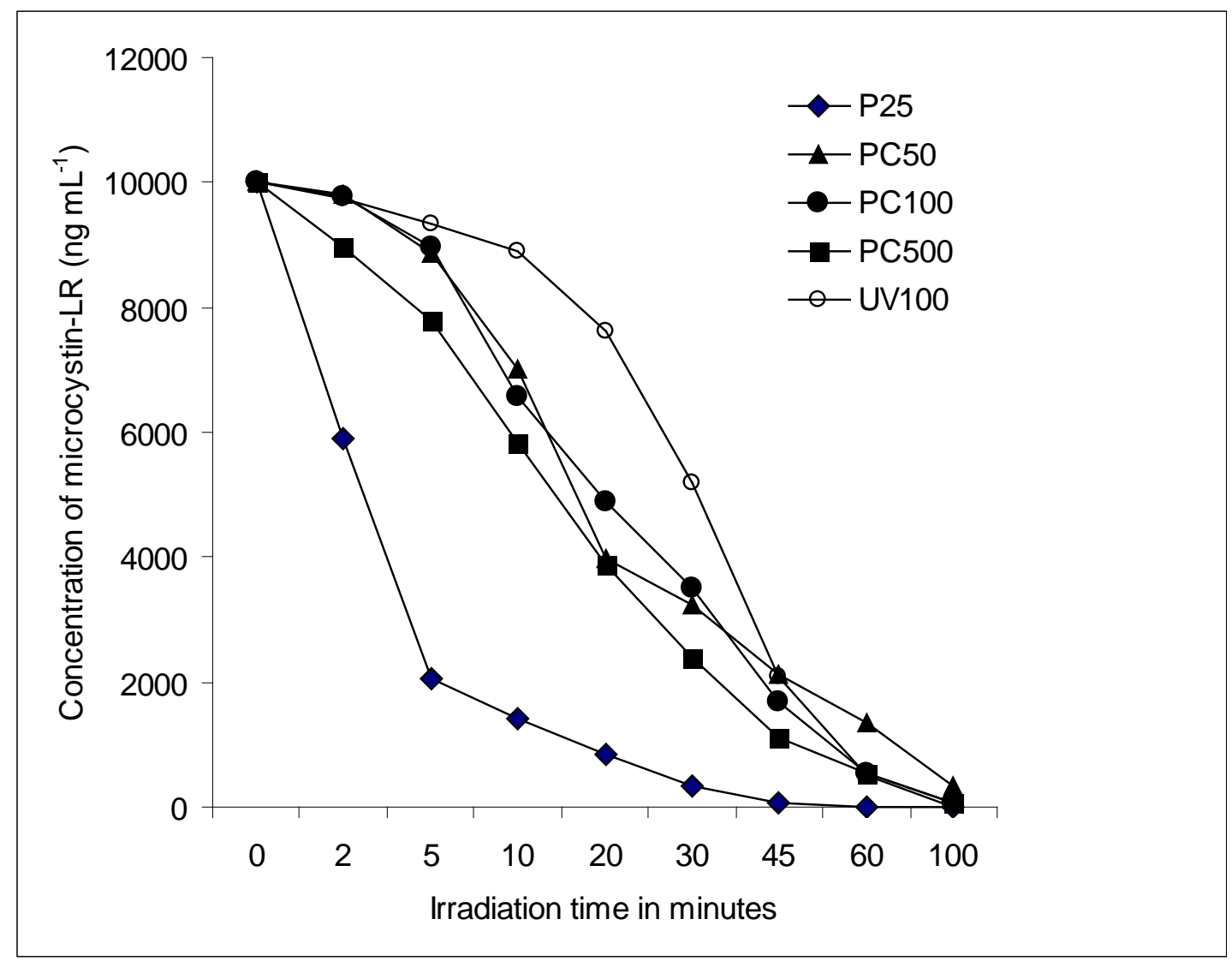

Figure 9. 
Table 1

\begin{tabular}{|c|c|}
\hline Species & References \\
\hline \multicolumn{2}{|l|}{$\overline{\text { Bacteria }}$} \\
\hline Coliforms & 58,59 \\
\hline Escherichia coli & $\begin{array}{l}9,10,11,12,36,37,42,45,56,57,68,72,75 \\
78,79,86\end{array}$ \\
\hline Salmonella spp. & 10 \\
\hline Pseudomonas aeruginosa & 10 \\
\hline Bacillus spp. & $40,62,64$ \\
\hline Clostridium perfringens & 35,63 \\
\hline Staphylococcus aureus & 52,87 \\
\hline Enterococcus spp. & 37,52 \\
\hline $\begin{array}{l}\text { Marine bacteria Alteromonas } \\
\text { alvinellae and Photobacterium } \\
\text { phosphoreum }\end{array}$ & 43 \\
\hline \multicolumn{2}{|l|}{ Viruses } \\
\hline Hepatitis B & 44 \\
\hline Bacteriophase MS-2 & 46,47 \\
\hline \multicolumn{2}{|l|}{ Fungi } \\
\hline Fusarium spp. & $48,49,50$ \\
\hline Pichia pastoris & 51 \\
\hline Candida albicans & 52 \\
\hline Aspergillus niger & 52 \\
\hline \multicolumn{2}{|l|}{ Protozoa } \\
\hline Giardia intestinalis & 53 \\
\hline Acanthamoeba castellani & 53 \\
\hline Cryptosporidium parvum & 54,55 \\
\hline
\end{tabular}


Table 2

\begin{tabular}{|l|l|}
\hline Metabolite & References \\
\hline Domoic acid & 127 \\
Brevotoxin & 129 \\
Shellfish toxin - saxitoxin & 130 \\
Microcystin & $101-120$ \\
Nodularin & 122 \\
Cylindrospermopsin & 123 \\
Anabena & 124 \\
Geosmin & $125-127$ \\
2-methylisoborneol(MIB) & 125,128 \\
\hline
\end{tabular}

